Portland State University

PDXScholar

\title{
Using Environmental Variables and Soil Processes to Forecast Denitrification Potential and Nitrous Oxide Fluxes in Coastal Plain Wetlands Across Different Land Uses
}

Jennifer L. Morse

Portland State University, jlmorse@pdx.edu

Marcelo Ardón

Duke University

Emily S. Bernhardt

Duke University

Follow this and additional works at: https://pdxscholar.library.pdx.edu/esm_fac

Part of the Environmental Monitoring Commons, and the Soil Science Commons Let us know how access to this document benefits you.

\section{Citation Details}

Morse, JL, Ardón, MM, Bernhardt, ES (2012). Using Environmental Variables and Soil Processes to Forecast Denitrification Potential and Nitrous Oxide Fluxes in Coastal Plain Wetlands Across Different Land Uses. Journal of Geophysical Research, Vol 117.

This Article is brought to you for free and open access. It has been accepted for inclusion in Environmental Science and Management Faculty Publications and Presentations by an authorized administrator of PDXScholar. Please contact us if we can make this document more accessible: pdxscholar@pdx.edu. 


\title{
Using environmental variables and soil processes to forecast denitrification potential and nitrous oxide fluxes in coastal plain wetlands across different land uses
}

\author{
Jennifer L. Morse, ${ }^{1,2}$ Marcelo Ardón, ${ }^{1,3}$ and Emily S. Bernhardt ${ }^{1}$ \\ Received 6 December 2011; revised 23 April 2012; accepted 25 April 2012; published 16 June 2012.
}

[1] We examined relationships between denitrification (DNF) and nitrous oxide $\left(\mathrm{N}_{2} \mathrm{O}\right)$ fluxes and potentially important chemical and physical predictors to build a predictive understanding of gaseous $\mathrm{N}$ losses from coastal plain wetlands. We collected soil, gas, and pore water samples from 48 sampling locations across a large (440 ha) restored wetland, an adjacent drained agricultural field, and nearby forested wetlands every two months over two years. In summer and fall 2007, we measured soil DNF potential (21.6-3560 $\mathrm{mg} \mathrm{N} \mathrm{m}^{-3} \mathrm{~d}^{-1}$ ) and $\mathrm{N}_{2} \mathrm{O}$ efflux $\left(-4.36-8.81 \mathrm{mg} \mathrm{N} \mathrm{m}^{-2} \mathrm{~d}^{-1}\right)$, along with 17 predictor variables. We developed statistical models for the most comprehensive subset of the data set (fall 2007) and used another subset (summer 2007) for cross-validation. Soil $\mathrm{pH}$ and total soil nitrogen were the best predictors of DNF potential $\left(\mathrm{R}_{\mathrm{adj}}^{2}=0.68\right)$. A regression using carbon dioxide flux and soil temperature together with soil extractable $\mathrm{NH}_{4}^{+}$and DNF potential explained $85 \%$ of the variation in fall $\mathrm{N}_{2} \mathrm{O}$ fluxes. The model for DNF performed reasonably well when cross-validated with summer data $\left(\mathrm{R}^{2}=0.40\right)$, while the $\mathrm{N}_{2} \mathrm{O}$ model did not predict summer $\mathrm{N}_{2} \mathrm{O}$ fluxes $\left(\mathrm{R}^{2}<0.1\right)$. Poor model performance was likely due to nonlinear responses to high temperatures and/or higher and more variable root respiration by plants during the growing season, leading to overprediction of $\mathrm{N}_{2} \mathrm{O}$ flux. Our results suggest that soil DNF potential may be modeled fairly effectively from a small number of soil parameters, that DNF potential is uncorrelated with $\mathrm{N}_{2} \mathrm{O}$ effluxes, and that successful estimation of wetland $\mathrm{N}_{2} \mathrm{O}$ effluxes will require finer-scale models that incorporate seasonal dynamics.

Citation: Morse, J. L., M. Ardón, and E. S. Bernhardt (2012), Using environmental variables and soil processes to forecast denitrification potential and nitrous oxide fluxes in coastal plain wetlands across different land uses, J. Geophys. Res., 117, G02023, doi:10.1029/2011JG001923.

\section{Introduction}

[2] Nitrous oxide $\left(\mathrm{N}_{2} \mathrm{O}\right)$, formed as a byproduct of microbial processes in soil and water, is a long-lived gas that destroys stratospheric ozone and contributes to the greenhouse effect [Bremner, 1997; Forster et al., 2007]. Nitrous oxide is primarily produced as a byproduct of the microbial processes of nitrification (NF), which converts ammonium $\left(\mathrm{NH}_{4}^{+}\right)$to nitrate $\left(\mathrm{NO}_{3}^{-}\right)$under oxic conditions, and denitrification (DNF), which converts nitrate $\left(\mathrm{NO}_{3}^{-}\right)$to inert atmospheric

\footnotetext{
${ }^{1}$ Department of Biology, Duke University, Durham, North Carolina,

${ }^{2}$ Now at Cary Institute of Ecosystem Studies, Millbrook, New York, USA.

${ }^{3}$ Now at Department of Biology, East Carolina University, Greenville, North Carolina, USA.

Corresponding author: J. L. Morse, Cary Institute of Ecosystem Studies, PO Box AB, Millbrook, NY 12545, USA. (morsej@caryinstitute.org)

C2012. American Geophysical Union. All Rights Reserved.
}

dinitrogen $\left(\mathrm{N}_{2}\right)$ gas under anoxic conditions [Knowles, 1982]. DNF can be a source (production) of $\mathrm{N}_{2} \mathrm{O}$ when DNF is incomplete due to high $\mathrm{NO}_{3}^{-}$availability or incomplete anoxia, as well as a sink (consumption) for $\mathrm{N}_{2} \mathrm{O}$, particularly under highly anoxic conditions and low $\mathrm{NO}_{3}^{-}$availability [Chapuis-Lardy et al., 2007; Firestone and Davidson, 1989]. $\mathrm{N}_{2} \mathrm{O}$ can be produced during NF (as a chemical byproduct of the ammonia oxidation step); it can also be produced or consumed by nitrifying bacteria under low oxygen $\left(\mathrm{O}_{2}\right)$ conditions which undergo nitrifier DNF [Poth and Focht, 1985; Wrage et al., 2001].

[3] Treatment wetlands and many wetland restoration projects seek to remove reactive forms of $\mathrm{N}\left(\mathrm{NH}_{4}^{+}\right.$and $\left.\mathrm{NO}_{3}^{-}\right)$that degrade water quality and affect human health [Carpenter et al., 1998; Townsend et al., 2003] by promoting NF and DNF [Mitsch et al., 2001; Zedler, 2003].Yet because both processes can be large sources of $\mathrm{N}_{2} \mathrm{O}$, an integrative assessment of their complex biological and environmental controls is required to understand whether $\mathrm{N}_{2} \mathrm{O}$ fluxes from $\mathrm{NF}$ and DNF represent a substantial offset to the water quality benefits of these processes [Schlesinger et al., 2006; Verhoeven et al., 2006]. 
[4] $\mathrm{N}_{2} \mathrm{O}$ fluxes are difficult to predict because they represent the net effect of multiple, interacting, and highly variable processes influenced by a variety of environmental factors. While several classifications and conceptual models of $\mathrm{N}_{2} \mathrm{O}$ controlling factors have been presented in the literature, the "hole-in-the-pipe" model of $\mathrm{N}$ gas emissions [Davidson et al., 2000; Firestone and Davidson, 1989] is one of the best known. This model describes three ways in which environmental factors functionally affect the flux of $\mathrm{N}$ gases, including $\mathrm{N}_{2} \mathrm{O}$ : (1) by controlling rates of NF and DNF; (2) by affecting the proportion of $\mathrm{N}_{2} \mathrm{O}$ produced by either process (hereafter the $\mathrm{N}_{2} \mathrm{O}$ yield); and (3) by controlling the flux of $\mathrm{N}_{2} \mathrm{O}$ from soil and water to the atmosphere.

[5] Rate-controlling factors include temperature, the availability of substrates [bioavailable carbon (C), $\mathrm{NH}_{4}^{+}$and $\mathrm{NO}_{3}^{-}$, and the presence of $\mathrm{O}_{2}$ [Firestone and Davidson, 1989; Firestone et al., 1980; Knowles, 1982]. Factors that control the $\mathrm{N}_{2} \mathrm{O}$ yield of NF and DNF include soil $\mathrm{pH}$, soil $\mathrm{O}_{2}$, and the ratio of electron donors to acceptors [Firestone et al., 1979; Gilmour, 1984; Šimek and Cooper, 2002; Weier et al., 1993]. Particularly in the denitrification pathway, where the terminal reductive step $\left(\mathrm{N}_{2} \mathrm{O} \rightarrow \mathrm{N}_{2}\right)$ has the lowest energy yield, the abundance of labile carbon relative to $\mathrm{NO}_{3}^{-}$has been shown to have a strong influence on $\mathrm{N}_{2} \mathrm{O}$ yield. When carbon availability is high relative to the supply of the electron donor $\mathrm{NO}_{3}^{-}$(high C: $\mathrm{NO}_{3}^{-}$) DNF tends to yield more $\mathrm{N}_{2}$, while low $\mathrm{C}: \mathrm{NO}_{3}^{-}$can result in more $\mathrm{N}_{2} \mathrm{O}$ [Firestone et al., 1980; Ullah and Moore, 2011]. For aerobic, chemoautotrophic nitrifiers, $\mathrm{N}_{2} \mathrm{O}$ yield is more sensitive to $\mathrm{O}_{2}$, with the highest $\mathrm{N}_{2} \mathrm{O}$ yields from $\mathrm{NF}$ observed at intermediate $\mathrm{O}_{2}$ availability or $40 \%-60 \%$ water filled pore space (WFPS). $\mathrm{N}_{2} \mathrm{O}$ yield from DNF is typically higher from soils and sediments with incomplete anoxia or $60 \%-80 \%$ WFPS [Davidson et al., 2000]. In addition to factors controlling $\mathrm{N}_{2} \mathrm{O}$ production, physical features of soils and sediment can affect the exchange of $\mathrm{N}_{2} \mathrm{O}$ between soil and the atmosphere. Soil particle size and drainage class can influence $\mathrm{N}_{2} \mathrm{O}$ fluxes by controlling the rate of gas diffusion between soil, water, and the atmosphere [Castellano et al., 2010; Davidson, 1991; Schindlbacher et al., 2004].

[6] Controlling factors operate at different spatial (from organisms to ecosystems) and temporal (from hourly to interannual) scales [Brumme et al., 1999; Groffman et al., 1987; Philippot et al., 2011; Wixon and Balser, 2009]. Proximal factors (e.g., availability of $\mathrm{O}_{2}, \mathrm{C}$, and $\mathrm{NO}_{3}^{-}$) operate at the organismal and microsite scale, while increasingly distal factors (e.g., water table depth, NF rates, soil type, and land use) affect DNF rates and $\mathrm{N}_{2} \mathrm{O}$ flux at the field and landscape scale [Groffman, 1991; Groffman et al., 1987]. Although soil parameters control fluxes of gases through soil pore spaces, they are generally measured at coarser scales and generally do not vary on annual timescales [Groffman, 1991]. Hydrologic parameters respond to weather events and climate trends, and can influence $\mathrm{N}_{2} \mathrm{O}$ fluxes on rapid time scales (minutes to hours) as well as seasonally, with freeze/thaw cycles and changes in evapotranspiration [Wu et al., 2010].

[7] These factors interact at multiple spatial and temporal scales, collectively influencing NF and DNF rates and $\mathrm{N}_{2} \mathrm{O}$ fluxes. In a wetland ecosystem, controls on $\mathrm{N}_{2} \mathrm{O}$ flux are particularly complex due to significant potential for consumption by DNF. Identifying important predictors could inform modeling and monitoring efforts, even if such predictors are likely to vary regionally or by ecosystem type [Groffman et al., 2000]. In restored wetlands influenced by agricultural nutrient loading, many conditions exist that could promote high rates of NF and DNF (high inorganic $\mathrm{N}$ from legacy fertilizers), and high $\mathrm{N}_{2} \mathrm{O}$ yields (low $\mathrm{C}$ relative to natural wetlands (low $\mathrm{C}: \mathrm{N}$ ), low $\mathrm{pH}$, variable soil moisture). Alternatively, $\mathrm{N}_{2} \mathrm{O}$ fluxes could be low if $\mathrm{pH}$ and $\mathrm{O}_{2}$ availability or physical properties inhibit $\mathrm{N}$ cycling rates, thus limiting the supply of $\mathrm{NO}_{3}^{-}$for DNF. If physical properties that are more stable or factors that are more temporally variable can be shown to be better predictors of $\mathrm{N}_{2} \mathrm{O}$ fluxes or DNF potential, such information could be incorporated into larger scale models of $\mathrm{N}_{2} \mathrm{O}$ flux and DNF and could be used to guide restoration practices and monitoring efforts.

[8] We conducted a multiyear study of gas fluxes from drained agricultural, recently restored, and forested wetlands of the NC coastal plain, finding differences among wetland types for soil characteristics such as $\mathrm{pH}$, soil organic $\mathrm{C}$, and $\mathrm{N}$ availability, as well as annual $\mathrm{N}_{2} \mathrm{O}$ fluxes [Morse et al., 2012]. For two comprehensive surveys, we measured a wide variety of potential predictors in an attempt to discover the most important and robust environmental correlates of $\mathrm{N}_{2} \mathrm{O}$ fluxes and DNF potential across a wide range of soil conditions, under the hypothesis that mechanisms controlling these processes would function similarly across wetland types. There is great interest worldwide in using environmental variables to forecast landscape-scale $\mathrm{N}_{2} \mathrm{O}$ fluxes to enable better understanding and regulation of greenhouse gas emissions [Olander and Haugen-Kozyra, 2011]. Our a priori prediction was that across all sites both DNF and $\mathrm{N}_{2} \mathrm{O}$ fluxes would be highest in intermittently flooded sites where variation in soil oxygen content would provide ideal conditions for $\mathrm{NF}$ and DNF to occur and where a high $\mathrm{N}_{2} \mathrm{O}$ yield from both processes would be expected. We anticipated that soil redox potential would be a good indicator of hydrologic and metabolic conditions leading to DNF and $\mathrm{N}_{2} \mathrm{O}$ emissions. We expected that the high soil $\mathrm{C}: \mathrm{NO}_{3}^{-}$ratios of undisturbed wetlands would lead to low DNF and $\mathrm{N}_{2} \mathrm{O}$ production, while the high $\mathrm{NO}_{3}^{-}$and low soil $\mathrm{C}$ content of the active agricultural field and recently restored wetlands would result in higher rates of DNF and higher $\mathrm{N}_{2} \mathrm{O}$ fluxes.

\section{Methods}

\subsection{Site Descriptions}

[9] This study focused on a 440 ha restored wetland (RW) and three reference sites (one agricultural field ( $\mathrm{Ag}$ ), and two forested wetlands (FW jointly; FW-dry and FW-wet)) in the Albemarle Peninsula in the Outer Coastal Plain of North Carolina. The Timberlake Restoration Project (TLRP) is a large, privately owned, compensatory mitigation site (1704 ha; $35^{\circ} 54^{\prime} 22^{\prime \prime} \mathrm{N}, 76^{\circ} 09^{\prime} 25^{\prime \prime} \mathrm{W}$ ), hydrologically connected to the Little Alligator River and to Albemarle Sound. The RW site historically contained swamp forest and pocosin ecosystems prior to drainage and agricultural conversion in the 1970 1980s; it was planted with freshwater wetland tree species (e.g., Taxodium distichum) in 2004 and hydrologically restored in February 2007 [Needham, 2006]. The site has been described in more detail in [Ardón et al., 2010] and [Morse et al., 2012]. The main soil series within RW are mapped as Ponzer muck (loamy, mixed, dysic, thermic Terric Haplosaprist) and Hyde loam (fine-silty, mixed, active, 
thermic Typic Umbraquult) [Natural Resources Conservation Service (NRCS), 2009].

[10] The three reference sites also are located on very poorly drained hydric soils. The drained agricultural site (Ag) adjacent to RW, currently planted in a corn and soybean rotation, is mainly comprised of Weeksville silt loam soils (coarse-silty, mixed, semiactive, thermic Typic Umbraquult) [NRCS, 2009]. One of the unmanaged forested wetlands is a preservation area (FW-dry) within TLRP in a minimally impacted mixed hardwood forest (oak-gum-cypress) [Needham, 2006] with soils mapped as Dorovan muck (dysic, thermic Typic Haplosaprist) [NRCS, 2009]. The other unmanaged forested wetland (FW-wet) is located $8 \mathrm{~km}$ away in the Palmetto Peartree Preserve, in a swamp hardwood stand of cypress and tupelo. Soils in FW-wet are mapped as Belhaven muck loamy, mixed, dysic, thermic Terric Haplosaprist [NRCS, 2009]. More complete descriptions can be found in [Morse et al., 2012].

\subsection{Field Sampling}

[11] Prior to hydrologic restoration in 2007, we established one transect within each of the two main soil types in RW ( $n=12$ sampling points in Hyde loam and 21 in Ponzer muck) along an elevation gradient, to capture the expected range of the flooding conditions. We set up five sampling points within each of the three reference sites (Ag, FW-dry, FW-wet). We collected soil samples $(0-15 \mathrm{~cm})$ and pore water samples from piezometers $(15 \mathrm{~cm}$ depth) in June and October 2007 from all 48 sampling points across the four sites. We measured $\mathrm{N}_{2} \mathrm{O}$ fluxes and related environmental variables every two months from July 2007 to June 2009. The methods and sampling approach for estimating gas fluxes are described extensively in [Morse et al., 2012]. Briefly, we applied the static chamber technique [Livingston and Hutchinson, 1995] to measure gas fluxes from soil and water to the atmosphere, from the accumulation rate of gas in the chamber headspace during incubations consisting of two 30-40 min intervals. Soil and air temperature were also measured during gas flux incubations. For other environmental variables, we also installed the following instruments at each of 48 sampling locations: one EC-5 soil moisture sensor (Decagon Devices, Pullman, Wash.) to measure volumetric water content, five platinum-tipped redox electrodes [Vepraskas and Faulkner, 2001] to measure soil redox potential with a voltmeter and calomel reference electrode (Fisher Scientific, Pittsburgh, Pa.), and one slotted PVC monitoring well with a water level recorder (Levelogger Gold or Silver, Solinst Instruments, Georgetown, Ontario, Canada) to record overlying water pressure and temperature every 15 min.

[12] This approach resulted in four groupings of predictor variables, based on the method of data collection and the timescales of variability: (1) soil properties; (2) soil microbial process variables; (3) soil nutrient pools; and (4) contemporaneously measured field-based variables (Table 1). Because summer and fall 2007 were abnormally dry [North Carolina Drought Management Advisory Council, 2008], the water table in many sampling points was below the depth of our monitoring wells and piezometers; we therefore had to exclude hydrologic variables related to water table depth and pore water chemistry altogether due to the number of missing observations.

\subsection{Laboratory Analyses}

[13] Concentrations of $\mathrm{CO}_{2}, \mathrm{~N}_{2} \mathrm{O}$, and $\mathrm{CH}_{4}$ in fieldcollected $9 \mathrm{~mL}$ glass vials were measured on a Shimadzu 17A gas chromatograph with electron capture and flame ionization detectors, retrofitted with 6-port valves and a methanizer in series with the flame ionization detector to measure the three gases from the same sample. Soil properties $[\mathrm{pH}$, bulk density (BD), \%C, \%N, and $\mathrm{C}: \mathrm{N}]$ were determined using standard methods. Soil chemical variables were measured on subsamples of fresh soil sieved with a 2-mm mesh. We extracted inorganic $\mathrm{N}$ from duplicate $2.5 \mathrm{~g}$ soil samples with $25 \mathrm{~mL} 2 \mathrm{M} \mathrm{KCl}$, and analyzed the extracts for $\mathrm{NH}_{4}^{+}$and $\mathrm{NO}_{3}^{-}$on a Lachat QuickChem 8000 automated system using the phenate method for $\mathrm{NH}_{4}^{+}$and the hydrazine reduction method for $\mathrm{NO}_{2}^{-}+\mathrm{NO}_{3}^{-}$(Lachat Instruments, Milwaukee, Wisc.). To determine soil dissolved organic $\mathrm{C}$ (DOC) and total dissolved $\mathrm{N}$ (TDN), we extracted duplicate $1 \mathrm{~g}$ (dry weight equivalent) subsamples of fresh soil with $30 \mathrm{~mL}$ of nanopure water for $15 \mathrm{~min}$ on a shaker table, centrifuged the samples at $3400 \mathrm{rpm}$ for $10 \mathrm{~min}$, and analyzed the filtered supernatant (Whatman GF/F filter) using a Shimadzu TOC$\mathrm{V}$ total carbon analyzer with a TNM-1 nitrogen module (Shimadzu Scientific Instruments, Columbia, Md.).

[14] Soil microbial processes were likewise determined on fresh soils and included DNF potential, net nitrification (NF), and active microbial biomass. Denitrification potential was measured as DNF enzyme activity (DEA) [Groffman et al., 1999; Tiedje et al., 1989]. In this anoxic assay, $5 \mathrm{~g}$ of soil in a slurry with excess $\mathrm{NO}_{3}^{-}$and labile $\mathrm{C}$ were incubated with acetylene, which blocks the activity of the nitrous oxide reductase enzyme, allowing the denitrification rate to be estimated through the accumulation of headspace $\mathrm{N}_{2} \mathrm{O}$. Net NF was estimated using a nitrapyrin-inhibition assay [Kemp and Dodds, 2002], in which parallel $5 \mathrm{~g}$ soil samples (with and without nitrapyrin, which blocks $\mathrm{NH}_{4}^{+}$oxidation) were incubated in centrifuge tubes for 7 days in the dark on a shaker table at $150 \mathrm{rpm}$ (aerated daily); accumulation of $\mathrm{NH}_{4}^{+}$due to blocked NF was measured on the Lachat QuickChem 8000. A protocol for estimating active microbial biomass by substrate-induced respiration (SIR) using autolyzed yeast as the substrate was modified from [West and Sparling, 1986] and [Bradford et al., 2008].

\subsection{Data Analysis and Modeling}

[15] We used data from fall 2007 (October 2007 soil sampling and November 2007 gas sampling) for model development and validation because it was the most comprehensive, with 48 sampling points and more ancillary information on soil and environmental variables available. We used the smaller summer 2007 data set (soil sampling from June and gas sampling in July 2007 at 21 sampling points) for model cross-validation. To put this subset of gas analyses into context with our previous work on biogeochemical differences by land use in these sites [Morse et al., 2012], we applied a site classification based on mean water level within the restored wetland (RW), yielding three subgroups with 5 sampling sites in each, for balanced comparisons to the reference sites: rarely flooded (water table within $0.1 \mathrm{~m}$ of the surface $5 \%$ of the time; RW-dry), intermittently flooded (water table within $0.1 \mathrm{~m}$ of the surface $24 \%$ of the time; RW-int), and mostly flooded (water table within $0.1 \mathrm{~m}$ 


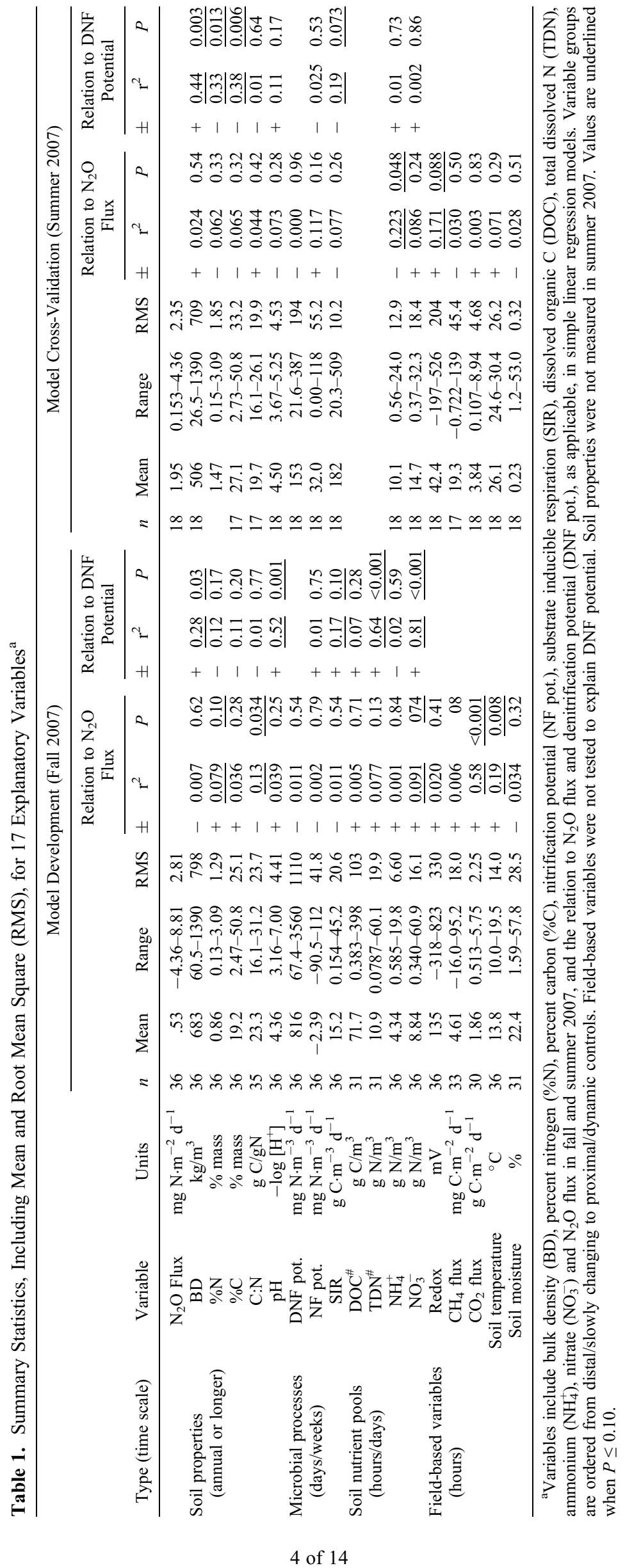



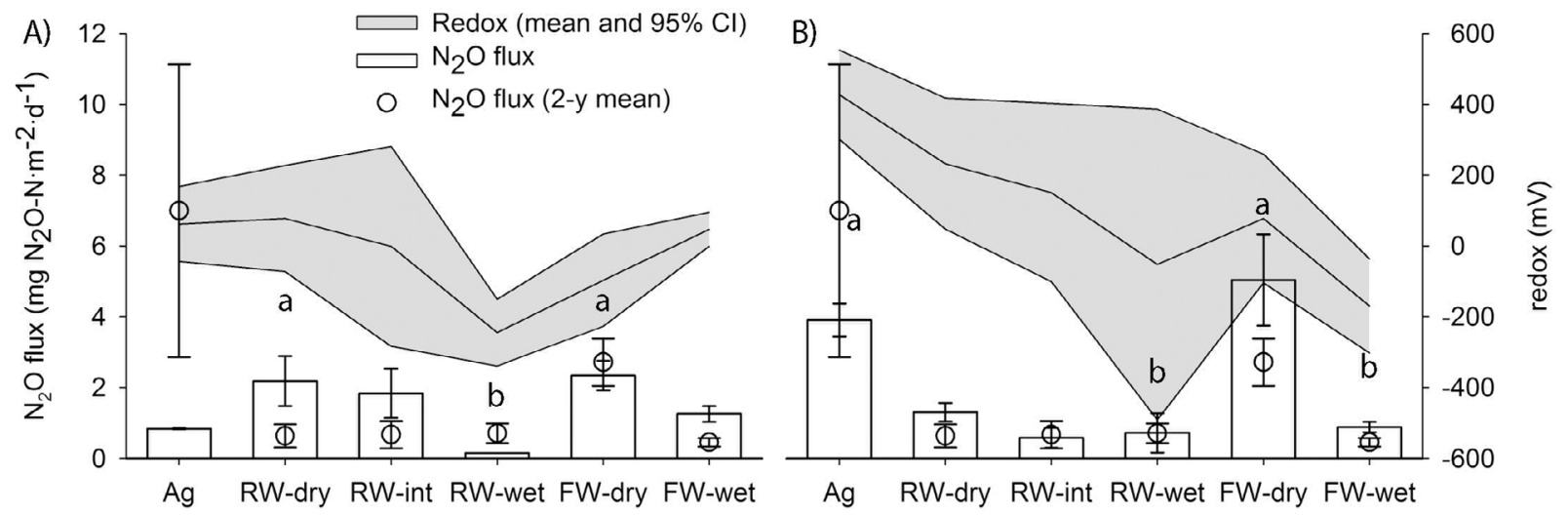

Figure 1. $\mathrm{N}_{2} \mathrm{O}$ fluxes and soil redox potential in (a) summer and (b) fall 2007. $\mathrm{N}_{2} \mathrm{O}$ flux results (means \pm $\mathrm{SE}$ ) are shown against $95 \%$ confidence interval of redox potential (right $y$ axis), displayed by site: agricultural field (Ag), restored wetland (RW) with three hydrologic classes (dry, intermittent, wet), and two forested wetland sites (FW-dry, FW-wet). Different letters indicate differences at $P<0.10$ in $\mathrm{N}_{2} \mathrm{O}$ flux among sites.

of the surface $82 \%$ of the time; RW-wet) [Morse et al., 2012]. For both summer and fall 2007 data sets, we tested group differences in DNF potential (as DEA) using permutation one-way tests with adjusted $P$-values for multiple comparisons between groups (oneway test and NemenyiDamico-Wolfe-Dunn test, R coin package) [Hothorn et al., 2008].

[16] We compiled soil and environmental variables from fall 2007 from 48 sampling points into a data set and excluded observations that had missing values for any predictor variables. We achieved a data set of 20 observations (out of a possible 48) that had no missing values for all potential predictors of $\mathrm{N}_{2} \mathrm{O}$ flux (18 predictors) and DNF potential (11 predictors). While hydrologic variables such as water level are undoubtedly important for understanding DNF, missing values forced us to exclude water level and variables related to pore water chemistry. We used principal components analysis (PCA; princomp; R package stats) [Venables and Ripley, 2002] to identify correlations between predictor variables and to see how observations clustered together according to land use in parameter space.

[17] We developed multiple linear regression models for $\mathrm{N}_{2} \mathrm{O}$ fluxes and DNF potential, but not for net nitrification; $\mathrm{NF}$ assays proved to be uninformative, with very low values across most observations, but those results were included in the subsequent data analysis as predictors of $\mathrm{N}_{2} \mathrm{O}$ fluxes and DNF potential. With nearly as many predictor variables as observations, we grouped predictor variables into four groups according to the method of measurement and estimated time-scale of variability - soil properties, soil microbial processes, soil nutrient pools, and field-based variablesto avoid overfitting the model. We then built regression models using each of four variable categories (submodels) to predict $\mathrm{N}_{2} \mathrm{O}$ flux and three of the variable groups (excluding field-based variables) to model potential DNF. While theoretical models might suggest nonlinear relationships between $\mathrm{N}_{2} \mathrm{O}$ flux and variables that control oxygen availability, such as soil moisture or water level [Davidson et al., 2000], we decided to use linear models as a simpler starting point and in accordance with similar studies [Davidson and Swank, 1986; Ullah and Moore, 2011].
[18] We used a stepwise method based on Akaike's Information Criterion (AIC) with forward and backward selection (stepAIC; R package MASS) [Venables and Ripley, 2002] to identify the combination of variables within each category that best fit the $\mathrm{N}_{2} \mathrm{O}$ flux data. We then combined the four best fitting submodels into one model and repeated the stepwise AIC model selection procedure to identify the overall models that best fit the $\mathrm{N}_{2} \mathrm{O}$ flux data. Final model comparisons were based on $\mathrm{AIC}_{\mathrm{c}}$ to account for small sample size [McQuarrie and Tsai, 1998]. We repeated this multiple regression process to develop a model for DNF potential using soil properties, soil microbial processes, and soil nutrient pools. Again, we built submodels for each category of variables, used stepwise AIC to identify the best submodels, and then combined the submodels to identify the two models that best fit the DNF potential data over all groups of variables. After building models for $\mathrm{N}_{2} \mathrm{O}$ flux and DNF potential using the fall 2007 data set $(n=20)$ with values for all candidate predictor variables, we tested model performance with observations from the same period that had been excluded from model building due to a missing value for one or more predictors $(n=10)$. We performed model cross-validation with input data from summer 2007 $(n=18)$, to test model performance across seasons.

\section{Results}

\subsection{DNF Potential and $\mathrm{N}_{2} \mathrm{O}$ Flux Patterns by Land Use Type}

[19] Measured $\mathrm{N}_{2} \mathrm{O}$ fluxes from summer and fall 2007 surveys encompassed much of the variation in $\mathrm{N}_{2} \mathrm{O}$ efflux observed throughout our two year study period, except in the agricultural field where $\mathrm{N}_{2} \mathrm{O}$ fluxes were substantially lower than the long-term mean in that site (Figure 1) [Morse et al., 2012]. Consistent with our findings from the longer study, $\mathrm{N}_{2} \mathrm{O}$ fluxes in the fall 2007 sampling period were significantly higher in the Ag and FW-dry sites than in the FW-wet and RW-wet sites $(P<0.10$; Figure $1 \mathrm{~b})$; in the summer survey, the highest $\mathrm{N}_{2} \mathrm{O}$ fluxes were measured in the drier portion of the restored wetland (RW-dry) and again in FWdry (Figure 1a). DNF potential in laboratory assays varied 

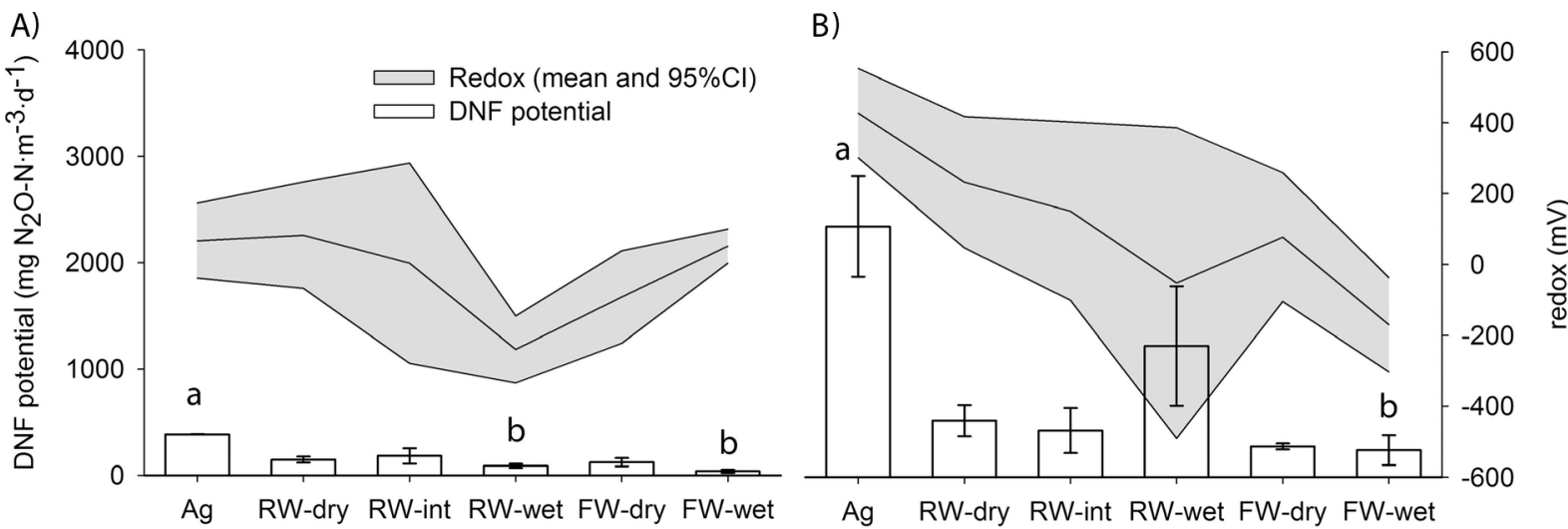

Figure 2. Denitrification potential and redox potential for soils collected in (a) summer and (b) fall 2007. DNF potential results (means $\pm \mathrm{SE}$ ) are shown against 95\% confidence interval of redox potential (right $y$ axis), displayed by site: agricultural field (Ag), restored wetland (RW) with three hydrologic classes (dry, intermittent, wet), and two forested wetland sites (FW-dry, FW-wet). Different letters indicate differences at $P<0.10$ in DNF potential among sites.

between 21.6 and $3570 \mathrm{mg} \mathrm{N} \mathrm{m} \mathrm{m}^{-3} \mathrm{~d}^{-1}$, but was only significantly and consistently different between the $\mathrm{Ag}$ and FW-wet sites in both summer and fall 2007 (Figure 2). Within the intensive survey data sets, neither $\mathrm{N}_{2} \mathrm{O}$ fluxes nor DNF potential showed a clear relationship with redox potential, and $\mathrm{N}_{2} \mathrm{O}$ flux patterns were not correlated with variation in DNF potential across sites (Figure 3).

\subsection{Distributions of and Correlations Between Predictor Variables}

[20] Prior to building multiple regression models for the fall 2007 data set, we examined the distributions of predictor variables and their relationships to $\mathrm{N}_{2} \mathrm{O}$ flux and DNF potential (Table 1). The highest variability across sampling points was seen in variables related to soil microbial processes, with intermediate variability found in soil solute and field-based variables, while the smallest range was seen in soil properties. We explored correlations of variables through PCA (Figure 4), with the first two components of the PCA together explaining $60 \%$ of the variation $(41 \%$ and $19 \%$, respectively) in environmental variables across sites. We found that many predictor variables were correlated (SIR, BD, redox, DOC, and NF at one end of axis 1, with $\mathrm{NH}_{4}^{+}, \% \mathrm{C}$ and $\% \mathrm{~N}$ at the opposite end), while the orthogonal axis grouped $\mathrm{NO}_{3}^{-}$, DNF potential, $\mathrm{CO}_{2}$ flux, $\mathrm{pH}$, TDN, and

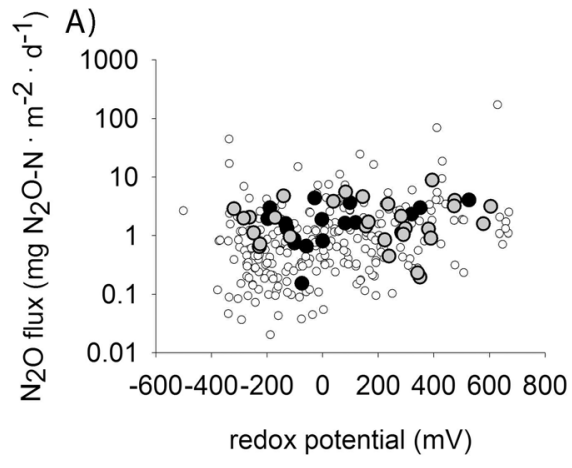

soil temperature (Figure 4a). Additionally, PCA revealed three clusters by land use, such that: (1) Ag sites were clearly separated from all other sites; (2) the forested wetland sites and three relatively wet sites within the restored wetland clustered together due to similarities; and (3) the remaining points within the restored wetland formed a third group (Figure 4b). Observations from the Ag site aligned with variables associated with soil fertilization, liming, and tillage (e.g., high $\mathrm{pH}, \mathrm{NO}_{3}^{-}$, and soil temperature), while observations from the forested wetlands and wetter sites within the RW aligned with variables that were associated with high organic matter (high soil $\mathrm{C}$ and $\mathrm{N}$ content, $\mathrm{NH}_{4}^{+}$, and soil moisture; Figure 4). The third grouping of variables, along which the drier RW sites were aligned, was directly opposite the organic matter gradient, and included variables such as SIR, DOC, redox potential, and bulk density (Figure 4). $\mathrm{CO}_{2}$ flux was aligned closely with $\mathrm{N}_{2} \mathrm{O}$ flux; these two variables were the only ones with a significant correlation to a principal component, PC2 in this case $(r=0.37$ and 0.39 , respectively; $P<0.10$; Figure $4 \mathrm{a}$ ).

\subsection{Multiple Regression Models for $\mathrm{N}_{2} \mathrm{O}$ Flux}

[21] Stepwise multiple regression with automated variable selection by AIC yielded submodels for $\mathrm{N}_{2} \mathrm{O}$ fluxes for each group of candidate variables (Table 2). Of the soil

B)

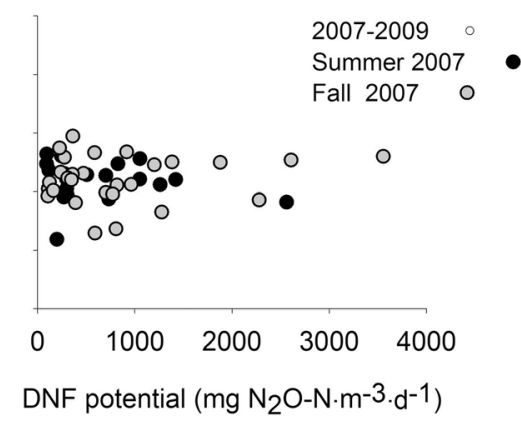

Figure 3. $\mathrm{N}_{2} \mathrm{O}$ fluxes (July 2007-June 2009) across all sites plotted against (a) redox potential and (b) denitrification potential (summer and fall 2007). Note log-scale on $y$ axis. 

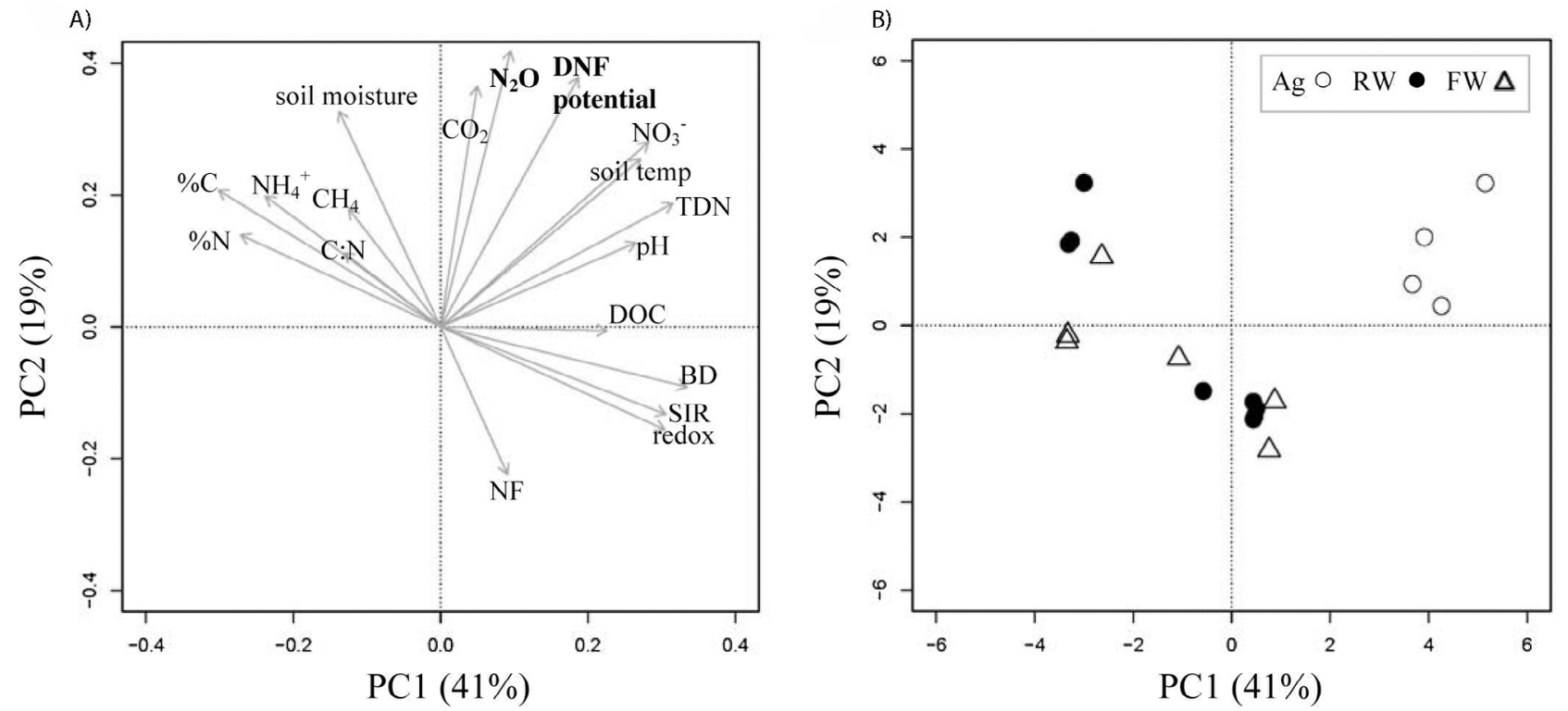

Figure 4. Biplots of principal components analysis showing (a) loadings of variables on the two principal components; and (b) scores on the two principal components for sampling points according to land use type (Ag: agricultural; RW: restored wetland; FW: forested wetland).

properties, $\% \mathrm{C}$ alone was the best predictor but only explained $5 \%$ of the variance in $\mathrm{N}_{2} \mathrm{O}$ flux $(P>0.05)$. The microbial process submodel was composed of DNF potential and NF potential $\left(\mathrm{R}_{\mathrm{adj}}^{2}=0.19 ; P=0.087\right)$, while the soil nutrient pools submodel selected $\mathrm{KCl}$-extractable $\mathrm{NO}_{3}^{+}$and $\mathrm{NH}_{4}^{+}\left(\mathrm{R}_{\mathrm{adj}}^{2}=0.39 ; P=0.0086\right)$. The best model from fieldbased contemporaneously measured variables found that soil $\mathrm{CO}_{2}$ flux and soil temperature explained $61 \%$ of the variance in $\mathrm{N}_{2} \mathrm{O}$ fluxes (Table 2). The four submodels were combined into one model with seven parameters, which was refined again using stepwise AIC variable selection. This process yielded the final $\mathrm{N}_{2} \mathrm{O}$ model based on four parameters: two field-based variables (soil $\mathrm{CO}_{2}$ flux and soil temperature), one soil nutrient pool variable $\left(\mathrm{NH}_{4}^{+}\right)$, and one microbial process variable (DNF potential), with $\mathrm{R}_{\text {adj }}^{2}$ of 0.85 . Bivariate plots of these individual predictors revealed significant positive linear relationships between $\mathrm{N}_{2} \mathrm{O}$ flux and the first three predictors (soil $\mathrm{CO}_{2}$ flux, temperature, and $\mathrm{NH}_{4}^{+}$ availability; $P<0.006$ ), while DNF potential alone had no significant relationship to $\mathrm{N}_{2} \mathrm{O}$ flux (Figure 5).

[22] The AIC values were corrected to $\mathrm{AIC}_{\mathrm{c}}$ to account for small sample size [McQuarrie and Tsai, 1998], and the model with the smallest $\mathrm{AIC}_{\mathrm{c}}$ was deemed to best fit the data given the competing models. The $\mathrm{w}_{\mathrm{i}}$ column in Table 2 represents the relative weight of each model given the competing models, allowing comparisons between models. The overall model for $\mathrm{N}_{2} \mathrm{O}$ flux had a weight of over 0.99 , meaning that there was very strong support for this model. In comparing only the submodels to one another, we found that the field-based model (soil $\mathrm{CO}_{2}$ flux and soil temperature) had a weight of 0.98 , vastly outperforming the other submodels when the overall best model was removed from the comparison (not shown).

\subsection{Model Fits and Model Validation for $\mathrm{N}_{2} \mathrm{O}$ Flux}

[23] The best fitting $\mathrm{N}_{2} \mathrm{O}$ model accounted for $85 \%$ of the variance in $\mathrm{N}_{2} \mathrm{O}$ flux, with soil $\mathrm{CO}_{2}$ flux as the most

Table 2. Model Selection Results for $\mathrm{N}_{2} \mathrm{O}$ Fluxes and Denitrification Potential, With Data From Fall 2007 as the Input Data Set $(n=20)^{\mathrm{a}}$

\begin{tabular}{|c|c|c|c|c|c|c|c|}
\hline & AIC - Selected Variables & $\mathrm{R}_{\mathrm{adj}}^{2}$ & $\mathrm{~K}$ & AIC & $\mathrm{AIC}_{\mathrm{c}}$ & $\mathrm{w}_{\mathrm{i}}$ & Rejected Variables \\
\hline $\mathrm{N}_{2} \mathrm{O}$ flux model & $\mathrm{CO}_{2}$.flux + soil.temp $+\mathrm{NH}_{4}^{+}-$DEA & 0.85 & 4 & -1.91 & 0.757 & 0.999 & \\
\hline \multicolumn{8}{|c|}{ Submodels } \\
\hline Soil properties & $\% \mathrm{C}$ & 0.05 & 1 & 34.4 & 34.6 & 0 & $\mathrm{BD}, \mathrm{C}: \mathrm{N}, \mathrm{pH}, \% \mathrm{~N}$ \\
\hline Microbial processes & DEA - NF & 0.08 & 2 & 33.6 & 34.3 & 0 & SIR \\
\hline Soil solutes & $\mathrm{NO}_{3}^{-}+\mathrm{NH}_{4}^{+}$ & 0.39 & 2 & 25.4 & 26.1 & 0 & DOC, TDN \\
\hline Field-based & $\mathrm{CO}_{2}$.flux + soil.temp & 0.61 & 2 & 16.2 & 16.1 & 0.001 & $\mathrm{CH}_{4}$, flux, redox, soil moisture \\
\hline DNF potential model & $\mathrm{pH}^{2}-\mathrm{pH}+\mathrm{NO}_{3}^{-}$ & 0.68 & 3 & 255 & 256 & 0.59 & \\
\hline \multicolumn{8}{|c|}{ Submodels } \\
\hline Soil properties & $\mathrm{pH}^{2}-\mathrm{pH}-\% \mathrm{~N}$ & 0.65 & 3 & 257 & 258 & 0.22 & $\mathrm{BD}, \% \mathrm{C}, \mathrm{C}: \mathrm{N}$ \\
\hline Microbial processes & SIR & 0.07 & 1 & 278 & 278 & 0 & $\mathrm{NF}$ \\
\hline Soil solutes & $\mathrm{NO}_{3}^{-}+\mathrm{NH}_{4}^{+}$ & 0.61 & 2 & 259 & 259 & 0.20 & DOC, TDN \\
\hline
\end{tabular}

${ }^{\mathrm{a}}$ For each model and submodel, the predictor variables selected and rejected are shown, as well as the adjusted $\mathrm{R}^{2}$, number of parameters (K), Akaike's Information Criterion (AIC) and corrected $\mathrm{AIC}\left(\mathrm{AIC}_{\mathrm{c}}\right)$, and the relative weight $\left(\mathrm{w}_{\mathrm{i}}\right)$ of each model given the other models. Italicized values identify the model that best fits the data. 

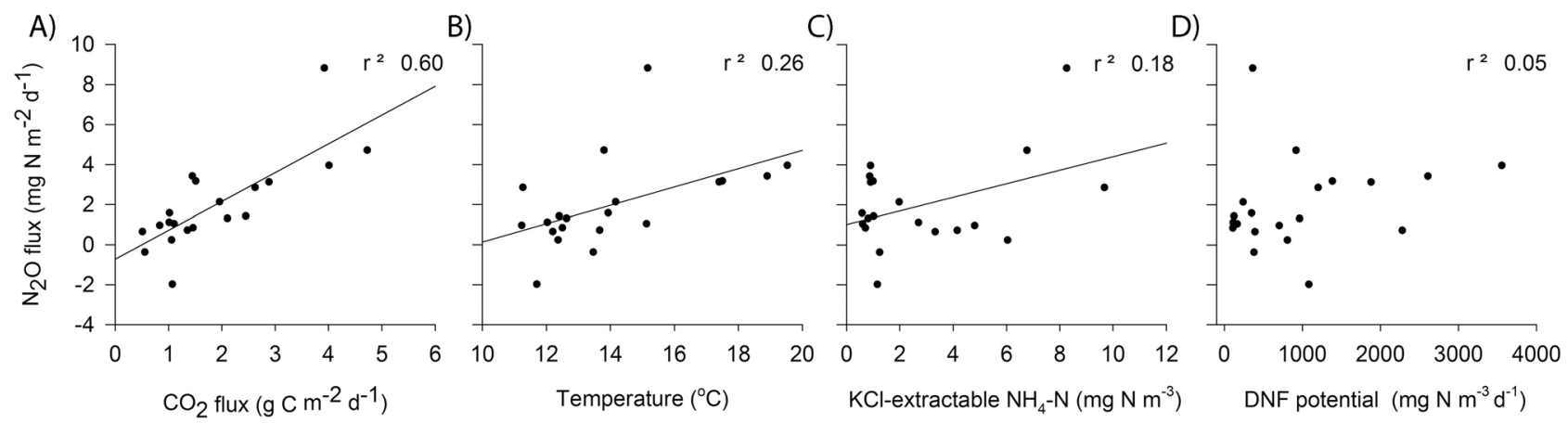

Figure 5. Bivariate relationships between $\mathrm{N}_{2} \mathrm{O}$ flux and individual predictor variables identified for best fit model: (a) soil $\mathrm{CO}_{2}$ flux; (b) soil temperature; (c) $\mathrm{KCl}$-extractable ammonium; and (d) DNF potential. Regression lines not shown when $r^{2} \leq 0.10$.

important predictor in the model, followed by soil temperature and $\mathrm{NH}_{4}^{+}\left(\mathrm{R}^{2}=0.89 ; \mathrm{R}_{\text {adj }}^{2}=0.85\right.$; Tables 2 and 3$)$. In the second best fitting $\mathrm{N}_{2} \mathrm{O}$ model, soil $\mathrm{CO}_{2}$ flux was over three times as important as soil temperature in explaining $\mathrm{N}_{2} \mathrm{O}$ flux (relative importance $=0.50$ and 0.16 , respectively). Soil temperature, $\mathrm{CO}_{2}$ flux, and $\mathrm{NH}_{4}^{+}$were each positively related to $\mathrm{N}_{2} \mathrm{O}$ flux, while DNF potential had a negative relationship. We plotted observed against fitted values for each model (Figure 6a) to see how the models captured the range of values. Both models appeared to perform well at intermediate and high values, but did not predict negative flux values well. When the $\mathrm{N}_{2} \mathrm{O}$ models were validated with data from the same time period but excluded from model building (because these data points lacked one or more of the 18 potential predictor variables but had results for the limited set of predictors included in the final model), they had similar fits (model $1 \mathrm{R}^{2}=0.73$ and model $\mathrm{R}^{2}=0.67$; Figure $6 \mathrm{~b}$ ). Both models when cross-validated with predictor data collected in summer 2007 performed poorly, with little predictive power $\left(\mathrm{R}^{2} \leq 0.10\right)$, and vastly overestimated observed $\mathrm{N}_{2} \mathrm{O}$ fluxes (Figure 6c).

\subsection{Multiple Regression Models for Denitrification Potential}

[24] The DNF potential modeling effort identified submodels for each category of soil variables, with the soil properties model and the soil nutrient pools model fitting the data well $\left(\mathrm{R}_{\mathrm{adj}}^{2}=0.65\right.$ and 0.61 , respectively; $P<$ $0.001)$. The soil properties model included $\% \mathrm{~N}, \mathrm{pH}$, and $(\mathrm{pH})^{2}$, while the soil nutrient pools model was based on $\mathrm{NO}_{3}^{-}$ and $\mathrm{NH}_{4}^{+}$(Table 2). With $\mathrm{pH}$ there was both a linear and quadratic relationship to DNF potential. Model selection for microbial process variables identified substrate-inducible respiration (SIR) as the best predictor of DNF potential, though it was not significant $\left(\mathrm{R}_{\mathrm{adj}}^{2}=0.07 ; P=0.27\right)$. The three submodels were combined into an overall model with six parameters, from which $\mathrm{NO}_{3}^{-}, \mathrm{pH}$, and $(\mathrm{pH})^{2}$ emerged as the best predictors of DNF potential by stepwise AIC model selection. Bivariate plots showed a significant quadratic relationship between DNF potential and $\mathrm{pH}\left(\mathrm{r}^{2}=0.69\right.$; Figure $7 \mathrm{a}$ ) and a significant positive linear relationship between DNF potential and $\mathrm{NO}_{3}^{-}$availability $\left(\mathrm{r}^{2}=0.62\right.$; Figure 7b). This overall model fit the DNF potential results well $\left(\mathrm{R}_{\mathrm{adj}}^{2}=0.68 ; P<0.001\right)$, and was the best fit to the data, with a relative weight of 0.59 , followed by the soil properties submodel with a weight of 0.22 (Table 2).

\subsection{Model Fits and Model Validation for Denitrification Potential}

[25] The two best models of DNF potential data had similarly good fits to the data $\left(\mathrm{R}_{\mathrm{adj}}^{2}=0.68\right.$ and $0.65, \mathrm{R}^{2}=0.74$ and 0.71 ; Tables 2 and 3 ). In the best fitting DNF potential

Table 3. Estimated Coefficients, Standard Errors, Relative Importance of Each Variable, and Proportion of Variance Explained ( $\left.\mathrm{R}^{2}\right)$ for the Two Best Models of $\mathrm{N}_{2} \mathrm{O}$ Flux and Denitrification Potential

\begin{tabular}{|c|c|c|c|c|c|c|c|c|c|}
\hline \multicolumn{5}{|c|}{$\mathrm{N}_{2} \mathrm{O}$ Flux } & \multicolumn{5}{|c|}{ DNF Potential } \\
\hline $\begin{array}{l}\text { Variable } \\
\text { Category }\end{array}$ & Variable & $\begin{array}{l}\text { Estimated } \\
\text { Coefficient }\end{array}$ & $\begin{array}{c}\text { Standard } \\
\text { Error }\end{array}$ & $\begin{array}{c}\text { Relative } \\
\text { Importance }\end{array}$ & $\begin{array}{l}\text { Variable } \\
\text { Category }\end{array}$ & Variable & $\begin{array}{c}\text { Estimated } \\
\text { Coefficient }\end{array}$ & $\begin{array}{c}\text { Standard } \\
\text { Error }\end{array}$ & $\begin{array}{c}\text { Relative } \\
\text { Importance }\end{array}$ \\
\hline Model 1 & (Int) & -10.5 & 1.69 & & & (Int) & $9.90 \times 10^{3}$ & $3.68 \times 10^{3}$ & \\
\hline Field-based & $\mathrm{CO}_{2}$.flux & 0.767 & 0.213 & 0.37 & Soil property & $\mathrm{pH}^{2}$ & 391 & 169 & 0.23 \\
\hline Field-based & soil.temp & 0.777 & 0.132 & 0.27 & Soil property & $\mathrm{pH}$ & $-3.87 \times 10^{3}$ & $1.56 \times 10^{3}$ & 0.20 \\
\hline Solute pool & $\mathrm{NH}_{4}^{+}$ & 0.432 & 0.0927 & 0.19 & Solute pool & $\mathrm{NO}_{3}^{-}$ & 29.9 & 17.6 & 0.31 \\
\hline \multirow[t]{2}{*}{ Microbial process } & DNF pot. & $-1.11 \times 10^{-3}$ & $2.91 \times 10^{-4}$ & 0.06 & & & & & $\mathrm{R}^{2}=0.74$ \\
\hline & & & & $\mathrm{R}^{2}=0.87$ & & & & & \\
\hline \multirow{5}{*}{$\begin{array}{l}\text { Model } 2 \\
\text { Field-based } \\
\text { Field-based }\end{array}$} & (Int) & -3.62 & 1.85 & & & (Int) & $1.27 \times 10^{4}$ & $3.50 \times 10^{3}$ & \\
\hline & $\mathrm{CO}_{2}$.flux & 1.26 & 0.287 & 0.50 & Soil property & $\mathrm{pH}^{2}$ & 570 & 135 & 0.37 \\
\hline & soil.temp & 0.230 & 0.139 & 0.16 & Soil property & $\mathrm{pH}$ & $-5.23 \times 10^{3}$ & $1.40 \times 10^{3}$ & 0.30 \\
\hline & & & & $\mathrm{R}^{2}=0.66$ & Soil property & $\% \mathrm{~N}$ & -150 & 164 & 0.04 \\
\hline & & & & & & & & & $\mathrm{R}^{2}=0.71$ \\
\hline
\end{tabular}


A)

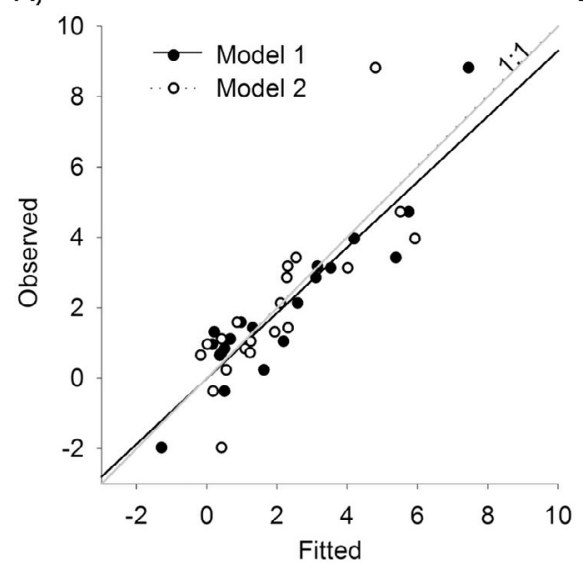

B)

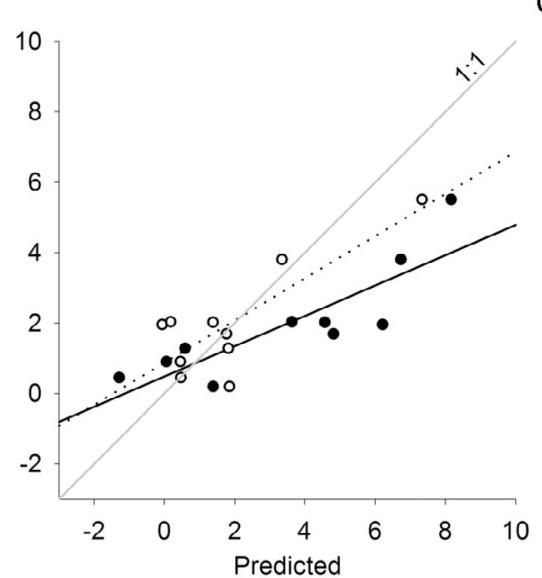

C)

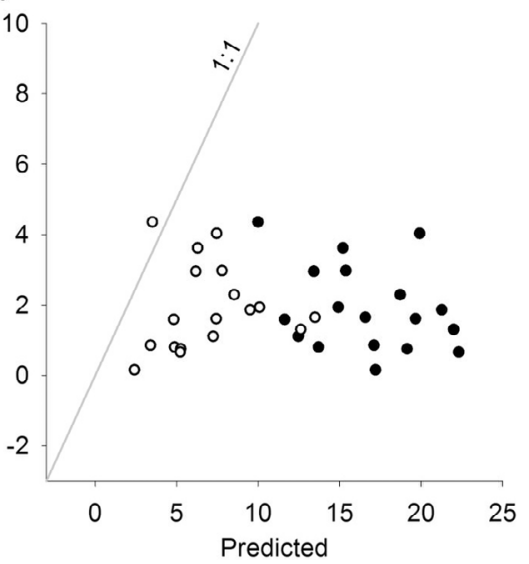

Figure 6. Model fits to observed data and validation of $\mathrm{N}_{2} \mathrm{O}$ models. (a) Fitted versus observed $\mathrm{N}_{2} \mathrm{O}$ flux for modeled data set (model 1 slope $=0.93$ and $\mathrm{R}^{2}=0.89$; model 2 slope $=1.00$ and $\mathrm{R}^{2}=0.65$ ); (b) validation of $\mathrm{N}_{2} \mathrm{O}$ models (model 1 slope $=0.43$ and $\mathrm{R}^{2}=0.73$; model 2 slope $=0.60$ and $\mathrm{R}^{2}=0.67$ ); and (c) cross-validation with data from summer 2007 (model 1 slope $=-0.10$ and $\mathrm{R}^{2}=0.10$; model 2 slope $=0.035$ and $\left.R^{2}<0.01\right)$. Regression lines not shown when $R^{2} \leq 0.10$.

model, $\mathrm{pH}$ accounted for $43 \%$ of the variance, with $\mathrm{NO}_{3}^{-}$ contributing $31 \%$ to the model. In the second best DNF potential model, $\mathrm{pH}$ again accounted for the bulk of the variance $(67 \%)$, with $\% \mathrm{~N}$ representing only $4 \%$. The $\mathrm{pH}$ and $(\mathrm{pH})^{2}$ coefficients were similar in both DNF potential models, with a U-shaped relationship and a minimum around pH 4.2 (Figure 7a). In the DNF potential models, DNF potential increased with increasing $\mathrm{NO}_{3}^{-}$in the first case and had a negative relationship to soil $\% \mathrm{~N}$ in the second case (Figures 7b-7c, Table 3). The fit of the two DNF potential models was similar, without major outliers in the data (Figure 8a). Validation of DNF potential models yielded very different results: Model 1 (including $\mathrm{pH}$ and $\mathrm{NO}_{3}^{-}$) fit the validation data set very poorly (slope $=0.28, \mathrm{R}^{2}=0.05$ ), but Model 2 (including $\mathrm{pH}$ and $\% \mathrm{~N}$ ) fit the validation data set better (slope $=0.65, \mathrm{R}^{2}=0.30, P=0.05$; Figure $8 \mathrm{~b}$ ). Crossvalidation of the DNF potential models with data from summer 2007 showed similar results to the validation tests, with Model 2 again fitting the data much better than Model 1, explaining $40 \%$ of the variance in DNF potential $(P=0.003$; Figure 8c).

\section{Discussion}

\subsection{Patterns in $\mathrm{N}_{2} \mathrm{O}$ Flux, Denitrification Potential, and Predictor Variables by Wetland Type}

[26] We expected $\mathrm{N}_{2} \mathrm{O}$ fluxes to be highest in sites with intermediate or fluctuating hydrology, and DNF potential to be highest where redox potential was lowest, but patterns in $\mathrm{N}_{2} \mathrm{O}$ fluxes and DNF potential across wetland land uses did not follow these expectations. Mean values and variability of $\mathrm{N}_{2} \mathrm{O}$ flux, redox potential, and DNF potential were higher in fall than in summer data sets. In both summer and fall data sets, the lowest $\mathrm{N}_{2} \mathrm{O}$ fluxes were measured in sites with lowest redox potentials (RW-wet) and one of the forested wetlands (FW-wet; fall only) (Figure 1). While this result could be consistent with complete DNF in these environments, DNF potential was not high in these sites. DNF

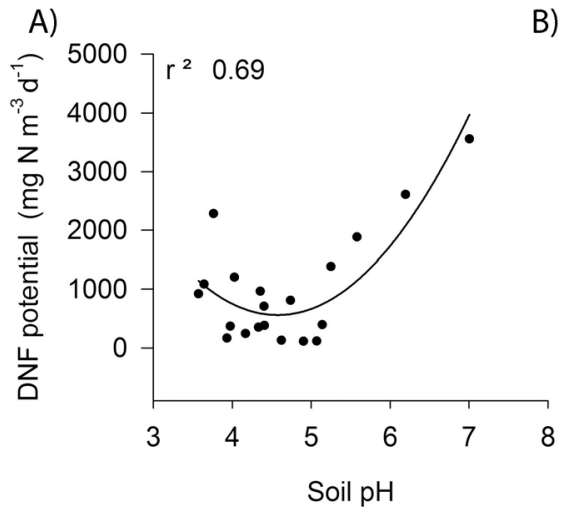

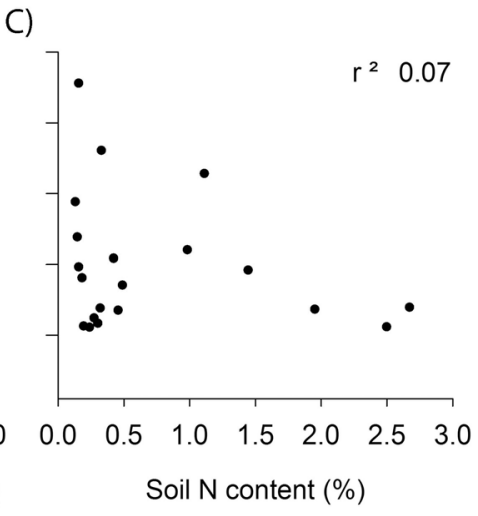

Figure 7. Bivariate relationships between DNF potential and individual predictor variables identified for best fit model: (a) soil pH; (b) KCl-extractable nitrate; and (c) soil $\mathrm{N}$ content. Regression lines not shown when $\mathrm{R}^{2} \leq 0.10$. 

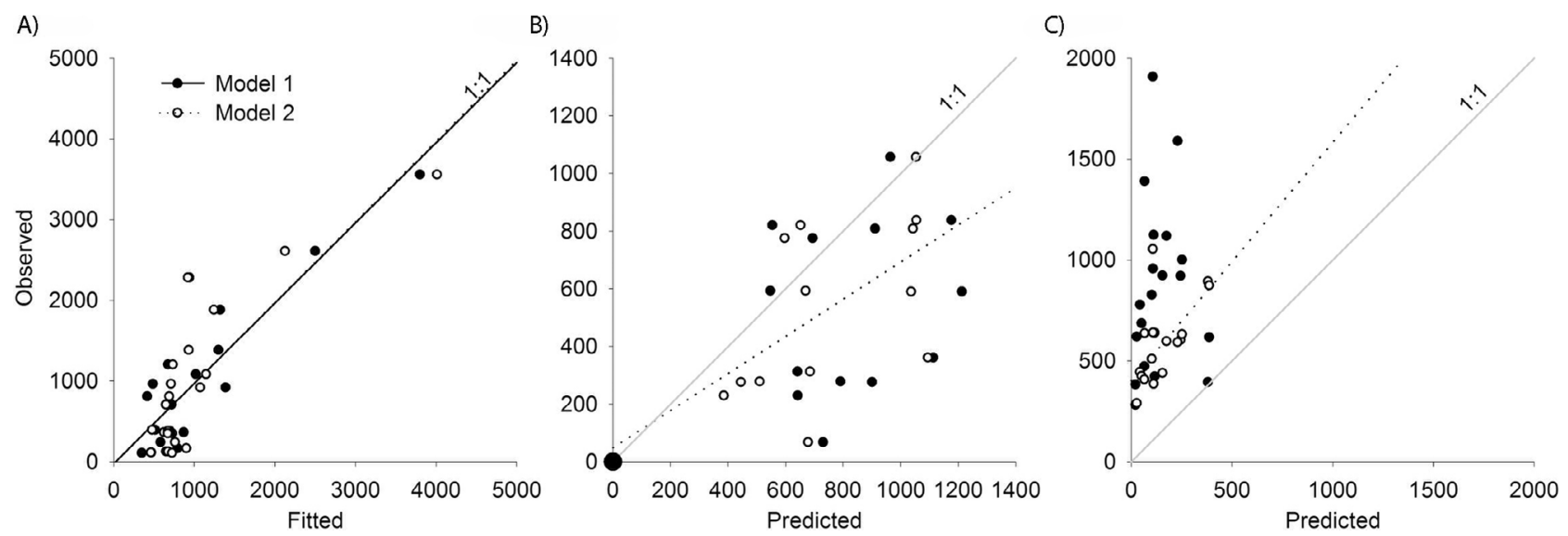

Figure 8. Model fits to observed data and validation of DNF potential models. (a) Fitted versus observed DNF potential for modeled data set (model 1 slope $=1.00$ and $\mathrm{R}^{2}=0.74$ and model 2 slope $=0.99$ and $\mathrm{R}^{2}=0.71$ ); (b) validation of DNF potential models 2 (model 1 slope $=0.28$ and $\mathrm{R}^{2}=0.05$ and model 2 slope $=0.65$ and $\mathrm{R}^{2}=0.30$ ); and (c) cross-validation with data from summer 2007 (model 1 slope $=$ -0.005 and $\mathrm{R}^{2}<0.01$; model 2 slope $=0.35$ and $\mathrm{R}^{2}=0.40$ ). Regression lines not shown when $\mathrm{R}^{2} \leq 0.10$.

potential was highest in both summer and fall in the Ag site, which also had the highest $\mathrm{N}_{2} \mathrm{O}$ fluxes and redox potential in fall. The FW-dry site, with relatively high $\mathrm{N}_{2} \mathrm{O}$ fluxes and intermediate redox potential, was the only site which aligned our expectations for $\mathrm{N}_{2} \mathrm{O}$ flux, but DNF potential was low in this site in both sampling periods. These results suggest that DNF could be the source of $\mathrm{N}_{2} \mathrm{O}$ in the $\mathrm{Ag}$ site, and that factors other than DNF were controlling $\mathrm{N}_{2} \mathrm{O}$ fluxes in the FW-dry site, which is consistent with results from a related ${ }^{15} \mathrm{~N}$ tracer study [Morse, 2010].

[27] In addition to the differences in $\mathrm{N}_{2} \mathrm{O}$ flux and DNF potential we found among sites, the principal components analysis (PCA) of predictor variables provided more evidence of differences among wetland types, identifying three distinct groupings by land use: (1) agricultural, (2) forested wetland and relatively wet RW, and (3) drier RW sites (Figure $4 \mathrm{~b}$ ). $\mathrm{N}_{2} \mathrm{O}$ fluxes and DNF potential were both positively related with PC2 (an axis of soil fertility and nitrogen availability), and not correlated at all to PC1 (related to organic matter and soil moisture), suggesting that $\mathrm{N}$ availability and $\mathrm{pH}$ status are more important drivers of $\mathrm{N}_{2} \mathrm{O}$ fluxes than organic $\mathrm{C}$ and moisture across these sites, and that these variables would be good predictors of both $\mathrm{N}_{2} \mathrm{O}$ flux and DNF potential, which is consistent with our regression models.

[28] We hypothesized initially that hydrologic variables would be primary controls on $\mathrm{N}_{2} \mathrm{O}$ fluxes, with highest rates at intermediate soil moisture or redox potential, due to contributions from both NF and DNF. We did not find a simple relationship between $\mathrm{N}_{2} \mathrm{O}$ fluxes and redox potential across the entire study period, or between $\mathrm{N}_{2} \mathrm{O}$ fluxes and either DNF or NF potentials, indicators of the two biological sources of $\mathrm{N}_{2} \mathrm{O}$ (Figure 2; NF results not shown). This was not surprising, given that multiple controls can interact to influence both NF and DNF rates, product ratios, and transport to the atmosphere [Brumme et al., 1999; Davidson, 1991; Wu et al., 2010]. In wetland sites with redox potentials that would be thermodynamically conducive to DNF, $\mathrm{NO}_{3}^{-}$ availability may be low enough that DNF rates are low, and any DNF activity may proceed through the terminal reductive step [e.g., Yu et al., 2008]. We conclude that DNF potential as measured by the DNF enzyme assay was not a good indicator of $\mathrm{N}_{2} \mathrm{O}$ flux patterns across land uses (Table 1). This finding is not surprising given that the DNF enzyme assay is meant to be a more stable indicator of DNF, while $\mathrm{N}_{2} \mathrm{O}$ fluxes may exhibit very large spatiotemporal variability [Groffman et al., 2000, 2006; Yanai et al., 2003].

\subsection{Predicting $\mathrm{N}_{2} \mathrm{O}$ Flux}

[29] Despite differences in $\mathrm{N}_{2} \mathrm{O}$ fluxes and DNF potentials among wetland types, we identified robust multiple regression models that fit observed $\mathrm{N}_{2} \mathrm{O}$ flux across agricultural soils, forested wetlands, and restored wetlands during fall 2007. We found that the best models for $\mathrm{N}_{2} \mathrm{O}$ fluxes depended primarily on $\mathrm{CO}_{2}$ flux and soil temperature, explaining $65 \%$ of the variance, with an additional $29 \%$ explained by $\mathrm{NH}_{4}^{+}$availability and DNF potential (Table 3 ). The tight relationship between $\mathrm{N}_{2} \mathrm{O}$ flux and $\mathrm{CO}_{2}$ flux has been recently demonstrated in a synthesis of gas exchange studies in eight ecosystems throughout the world, which found a slope of $0.66\left(\mathrm{r}^{2}=0.79\right)$ in rice paddies, $0.19\left(\mathrm{r}^{2}=\right.$ $0.66)$ in temperate forests, and $0.16\left(\mathrm{r}^{2}=0.79\right)$ in dry croplands [Xu et al., 2008]. In our data set, in a model with soil $\mathrm{CO}_{2}$ flux alone, the slope was $0.52\left(\mathrm{r}^{2}=0.58 ; P<0.001\right.$; Table 1), placing our study sites closer to rice paddies than temperate forests or croplands. Soil $\mathrm{CO}_{2}$ flux is used to represent $\mathrm{C}$ availability in some simulation models of $\mathrm{N}$-gas products from DNF, such as DAYCENT [Del Grosso et al., 2000]. The temperature sensitivity of $\mathrm{N}_{2} \mathrm{O}$ emissions has been shown to depend in part on $\mathrm{N}$ availability, with lower temperature responses in N-limited forests [Barnard et al., 2005; Grant and Pattey, 2008; Schindlbacher et al., 2004]. The correlation of $\mathrm{N}_{2} \mathrm{O}$ fluxes with soil $\mathrm{CO}_{2}$ fluxes and temperature shows that these environmental variables could be useful for predictive purposes because they integrate physical parameters, such as gas diffusivity and solubility, with biological factors such as respiration and enzyme activities that increase soil $\mathrm{C}$ and $\mathrm{N}$ availability and cycling.

[30] While robust models emerged for $\mathrm{N}_{2} \mathrm{O}$ fluxes across all sampling points during fall 2007, when applied to data 
from summer 2007, both models over-predicted $\mathrm{N}_{2} \mathrm{O}$ flux, with poor fit to observed values (Figure 6c). The range of $\mathrm{N}_{2} \mathrm{O}$ fluxes in summer 2007 was smaller over all sites, compared to the fall data set, which included more observations of negative $\mathrm{N}_{2} \mathrm{O}$ flux (Table 1). The most likely explanation for poor model performance in predicting summer $\mathrm{N}_{2} \mathrm{O}$ fluxes is that much higher root respiration by plants during the growing season would increase soil $\mathrm{CO}_{2}$ flux without necessarily affecting $\mathrm{N}_{2} \mathrm{O}$ production, leading to over-prediction of $\mathrm{N}_{2} \mathrm{O}$ flux. For this to be true, root respiration would have to vary substantially across sites, rather than being a constant proportion of soil respiration, which can range from $30 \%$ to $50 \%$ [Schlesinger and Andrews, 2000]. While this is plausible, given that the vegetation cover varies across these sites from soybeans/corn crops to young forest with dense grassland understory to mature forest, it is not something we could estimate after the fact. Our model also did not include any estimate of plant $\mathrm{N}$ demand, which could limit $\mathrm{N}$ availability during the growing season. Temperatures were higher in July than November 2007, which could explain lack of fit due to temperature, if a nonlinear relationship between temperature and $\mathrm{N}_{2} \mathrm{O}$ fluxes were more appropriate across seasons. These results suggest that simple models of $\mathrm{N}_{2} \mathrm{O}$ flux based on soil respiration may be most applicable outside the growing season, when root respiration and plant $\mathrm{N}$ uptake are not major factors.

[31] The role of $\mathrm{N}$ availability and DNF in regulating $\mathrm{N}_{2} \mathrm{O}$ fluxes in our models was not straightforward. We expected that high soil $\mathrm{NO}_{3}^{-}$content would lead to high DNF and $\mathrm{N}_{2} \mathrm{O}$ production, while high soil $\mathrm{C}$ would promote the production of $\mathrm{N}_{2}$ over $\mathrm{N}_{2} \mathrm{O}$ in DNF. Although $\mathrm{NH}_{4}^{+}$and $\mathrm{NO}_{3}^{-}$together helped to explain $39 \%$ of the variation in $\mathrm{N}_{2} \mathrm{O}$ flux in the soil solute submodel (Table 2), the final model included $\mathrm{NH}_{4}^{+}$ rather than $\mathrm{NO}_{3}^{-}$as a predictor, perhaps because $\mathrm{NO}_{3}^{-}$was already strongly correlated with soil temperature and soil $\mathrm{CO}_{2}$ flux (Figure 4). Since we found a positive relationship between $\mathrm{NH}_{4}^{+}$and $\mathrm{N}_{2} \mathrm{O}$ flux in the best fitting $\mathrm{N}_{2} \mathrm{O}$ model, one explanation could be that $\mathrm{N}_{2} \mathrm{O}$ fluxes are dominated by nitrification, or coupled nitrification-denitrification, driven by high $\mathrm{NH}_{4}^{+}$availability in these wetlands. While we have no evidence for direct $\mathrm{NF}$ emissions of $\mathrm{N}_{2} \mathrm{O}$ to explicitly support or refute this interpretation, our best fit model for $\mathrm{N}_{2} \mathrm{O}$ flux does suggest that more $\mathrm{N}_{2} \mathrm{O}$ is produced in soils with higher soil $\mathrm{CO}_{2}$ flux, temperature, and $\mathrm{NH}_{4}^{+}$, and lower DNF potential. The simplest explanation is that NF, or coupled NF-DNF, was a major contributor to $\mathrm{N}_{2} \mathrm{O}$ fluxes during the fall season. This interpretation is also supported by laboratory ${ }^{15} \mathrm{~N}$ stable isotope tracer experiments which demonstrated a higher ${ }^{15} \mathrm{~N}_{2} \mathrm{O}$ yield from soil cores from these sites amended with ${ }^{15} \mathrm{NH}_{4}^{+}$than from cores amended with ${ }^{15} \mathrm{NO}_{3}^{-}$[Morse, 2010]. Alternatively, the "leaky pipe" model [Davidson, 1991] proposes that incomplete DNF would also yield high $\mathrm{N}_{2} \mathrm{O}$ flux under conditions of excess $\mathrm{N}$ availability and low DNF potential, which is also consistent with the parameters in our multiple regression model (Table 2).

[32] Soil redox potential was not the integrator of hydrologic and metabolic conditions that we expected: redox potential alone was not correlated with $\mathrm{N}_{2} \mathrm{O}$ flux (Figure 3), and did not contribute to the overall $\mathrm{N}_{2} \mathrm{O}$ flux model. Potentially important finer-scale spatial and temporal dynamics, such as pulsed emissions of $\mathrm{N}_{2} \mathrm{O}$ or lags between controlling variables and $\mathrm{N}_{2} \mathrm{O}$ fluxes, were not captured in our modeling approach. It has been shown that point measurements of redox potential in the soil may not adequately reflect the conditions in microsites within the soil where $\mathrm{N}_{2} \mathrm{O}$ is produced [ $\mathrm{Yu}$ et al., 2006]. Covariance between predictor variables could also perhaps explain why certain variables we expected to be important did not emerge as significant predictors in our analysis. Factors known to be important for DNF that surprisingly were not selected for the final models were variables related to $\mathrm{C}$ availability, soil $\mathrm{pH}$, and active microbial biomass; however they were likely correlated with parameters in the models: carbon quality and availability were related to $\mathrm{CO}_{2}$ flux, while soil $\mathrm{pH}$ was negatively correlated with $\mathrm{NH}_{4}^{+}$ (Figure 4a).

\subsection{Multiple Regression Models for Denitrification Potential}

[33] With respect to DNF potential, we found that $\mathrm{pH}$ was the single most important variable in the two best fitting models. The influence of ongoing liming in the Ag site, along with waning effects of past liming in RW has led to a wide range in soil $\mathrm{pH}$ across land use types (3.75 in RW-wet to 5.53 in $\mathrm{Ag}$ ) [Morse et al., 2012]. Other studies have found that $\mathrm{pH}$ below 4 tends to inhibit DNF in laboratory settings [e.g., van den Heuvel et al., 2011]; however, in acid soils below $\mathrm{pH} \mathrm{4}$, it appears that microbial communities can be adapted to and denitrify at low pH [Parkin et al., 1985; Simek and Cooper, 2002; Weier and Gilliam, 1986]. Our survey showed DNF optima at the low and high ends of our $\mathrm{pH}$ gradient, such that the relationship between DNF and $\mathrm{pH}$ was U-shaped, with DNF potential minimized at $\mathrm{pH}$ 4.2. The other important factors in DNF potential models were related to $\mathrm{N}$ availability, with $\mathrm{KCl}$-extractable $\mathrm{NO}_{3}^{-}$and $\% \mathrm{~N}$ explaining $31 \%$ and $4 \%$ of the variation in DNF potential, respectively, in the two best fitting models (Table 3). Nitrate is one of the required substrates for denitrification, and thus the positive relationship to DNF potential was expected [Groffman, 1991]. In the second-best DNF potential model, soil $\mathrm{N}$ content was negatively related to DNF potential, which is not intuitive. In the PCA plot (Figure 4a), soil \%N was positively correlated with $\% \mathrm{C}$ and $\mathrm{NH}_{4}^{+}$availability, factors that could indicate lower NF rates [Reddy and Patrick, 1975; Strauss and Lamberti, 2000], and lower $\mathrm{NO}_{3}^{-}$supplies for DNF in these sites (Figure 4a). Model validation and cross-validation offered stronger support for the second-best model (with $\mathrm{pH}$ and $\% \mathrm{~N}$ as predictors), which fit observed DNF potential in both fall and summer $2007\left(R^{2}=0.30\right.$ and 0.40 , respectively; Figure 6). This suggests that $\mathrm{NO}_{3}^{-}$availability is more dynamic than DNF potential, and as such may not be useful for predicting values of an assay that integrates soil properties, microbial processes, and environmental variables over longer periods than measurements of soil $\mathrm{N}$ pools or in situ $\mathrm{N}$ cycling rates [Groffman et al., 1999; McGill et al., 2010].

\subsection{Spatial and Temporal Aspects of Factors Controlling $\mathrm{N}_{2} \mathrm{O}$ Flux and DNF Potential}

[34] Soil biogeochemical processes, like DNF, are often thought to be controlled by factors at multiple levels in a complex system [Brumme et al., 1999; Wixon and Balser, 2009]. We aimed to identify relationships between $\mathrm{N}_{2} \mathrm{O}$ flux and a suite of environmental variables that change over 
different time scales. By comparing the relative influence of distal, slowly changing variables (e.g., soil properties) versus more proximal, rapidly changing variables (e.g., soil $\mathrm{NO}_{3}^{-}$pools or soil temperature) we hoped to provide insights that could be useful for monitoring and modeling $\mathrm{N}_{2} \mathrm{O}$ fluxes and denitrification more broadly [Groffman, 1991; Groffman et al., 2009]. Organizing controlling factors into a hierarchy should ultimately allow us to construct more mechanistic and realistic models than classifying predictors as ratecontrolling, yield-controlling, or flux-controlling variables as per Davidson [1991].

[35] We found that $\mathrm{N}_{2} \mathrm{O}$ fluxes across all sampling points during one season were best predicted by either two contemporaneously field-measured variables (soil $\mathrm{CO}_{2}$ flux and soil temperature) or with an additional microbial process variable (DNF potential) and one soil nutrient variable $\left(\mathrm{NH}_{4}^{+}\right.$ availability). Some studies have shown $\mathrm{N}_{2} \mathrm{O}$ fluxes to be predictable based on general soil characteristics such as soil C:N [Klemedtsson et al., 2005], or multiple factors including bulk density, precipitation regime, and plant community [Brumme et al., 1999]. However, the fact that more dynamic variables were most useful in predicting $\mathrm{N}_{2} \mathrm{O}$ fluxes in this study, and that the influence of these factors over $\mathrm{N}_{2} \mathrm{O}$ fluxes changes temporally, is not surprising [Groffman, 1991; Harms and Grimm, 2008], given that $\mathrm{N}_{2} \mathrm{O}$ fluxes tend to have high variability in space and time [Harms and Grimm, 2012; Toma et al., 2010; Yanai et al., 2003]. Conversely, the DNF potential model based on two soil property variables $(\mathrm{pH}$ and $\% \mathrm{~N})$ fit the validation and cross-validation data sets much better than the model based on one soil property variable $(\mathrm{pH})$ and one soil nutrient variable $\left(\mathrm{NO}_{3}^{-}\right.$availability; Figure 7). This again suggests that $\mathrm{NO}_{3}^{-}$availability may be too dynamic to predict DNF potential, even if it may control DNF rates. Further, DNF potential in summer 2007 was predicted reasonably well $\left(\mathrm{R}^{2}=0.42\right)$ by two soil properties, so it may be a robust parameter that likewise does not change very rapidly in these sites.

\subsection{Denitrification and $\mathrm{N}_{2} \mathrm{O}$ Fluxes in Restored Wetlands}

[36] This study found that contemporaneously measured environmental variables were the best predictors of $\mathrm{N}_{2} \mathrm{O}$ fluxes for a given sampling event across a range of wetland land uses, and that soil $\mathrm{N}$ availability and DNF potential can provide additional predictive ability for such models. Although there is much support in the literature for hydrologic controls over soil $\mathrm{N}_{2} \mathrm{O}$ effluxes [Davidson et al., 2000; Hernandez and Mitsch, 2006; Yu et al., 2008], we did not find evidence for this during summer and fall 2007, which was a relatively dry period. For both $\mathrm{N}_{2} \mathrm{O}$ flux and DNF potential, $\mathrm{N}$-related variables were more informative than $\mathrm{C}$ availability in these organic, acidic soils. Given that many similar restored wetlands receive $\mathrm{N}$-enriched agricultural effluent, such $\mathrm{N}$ inputs are likely to drive $\mathrm{N}_{2} \mathrm{O}$ fluxes and DNF more than $C$ availability. To determine whether a wetland restoration site is a significant source of $\mathrm{N}_{2} \mathrm{O}$ fluxes, we recommend that both spatial and temporal variability at appropriate scales be addressed through measurement or models [Brumme et al., 1999]. However, in this restored wetland, $\mathrm{N}_{2} \mathrm{O}$ fluxes over two years were significantly lower than in adjacent agricultural fields and a nearby forested wetland [Morse et al., 2012], while water quality benefits attributed to DNF were substantial [Ardón et al., 2010]. This suggests $\mathrm{N}_{2} \mathrm{O}$ fluxes should not be considered an impediment to wetland restoration in similar coastal freshwater sites with agricultural $\mathrm{N}$ loading.

[37] We found the relative temporal stability of DNF potential encouraging since the assay was developed to facilitate cross-system comparisons and to give a broader view of DNF, given that actual DNF rates are difficult to measure and are highly variable [Groffman et al., 2006]. On the other hand, these qualities make DEA assays a relatively blunt tool for assessing responses to seasonal changes or weather events, and suggest that DNF potential is only partially useful for predicting sensitive and rapidly changing variables such as field $\mathrm{N}_{2} \mathrm{O}$ fluxes. Our analyses in this study could not distinguish between nitrification and denitrification as sources of $\mathrm{N}_{2} \mathrm{O}$ in these wetlands, but model results suggest that NF-derived $\mathrm{N}_{2} \mathrm{O}$ is likely to be a larger component of $\mathrm{N}_{2} \mathrm{O}$ emissions than has previously been considered.

[38] Acknowledgments. We are very grateful to R. Bier and M. Burke-Scoll for help in both the field and the laboratory. We thank Curt Richardson, the staff of the Duke Wetlands Center, Peter Groffman, and two anonymous reviewers for their contributions. This research was supported by a private gift from Great Dismal Swamp Mitigation Bank in support of basic research, grant 70233 from North Carolina's Water Resource Research Institute, a small grant for monitoring equipment from NC DENR, and a grant to E.S. Bernhardt from the U.S. Department of Energy's Office of Science (BER) through the Coastal Center of the National Institute for Climatic Change Research at Tulane University. J. L. Morse was supported by a U.S. Environmental Protection Agency Science to Achieve Results (STAR) Fellowship (FP916599), and M. Ardón was supported by NSF DBI- 085576 .

\section{References}

Ardón, M., J. Morse, M. Doyle, and E. Bernhardt (2010), The water quality consequences of restoring wetland hydrology to a large agricultural watershed in the southeastern Coastal Plain, Ecosystems (N. Y.), 13(7), 1060-1078, doi:10.1007/s10021-010-9374-x.

Barnard, R., P. W. Leadley, and B. A. Hungate (2005), Global change, nitrification, and denitrification: A review, Global Biogeochem. Cycles, 19(1), GB1007, doi:10.1029/2004GB002282.

Bradford, M. A., N. Fierer, and J. F. Reynolds (2008), Soil carbon stocks in experimental mesocosms are dependent on the rate of labile carbon, nitrogen and phosphorus inputs to soils, Funct. Ecol., 22(6), 964-974, doi:10.1111/j.1365-2435.2008.01404.x

Bremner, J. M. (1997), Sources of nitrous oxide in soils, Nutr. Cycl. Agroecosyst., 49(1/3), 7-16, doi:10.1023/A:1009798022569.

Brumme, R., W. Borken, and S. Finke (1999), Hierarchical control on nitrous oxide emission in forest ecosystems, Global Biogeochem. Cycles, 13(4), 1137-1148, doi:10.1029/1999GB900017.

Carpenter, S. R., N. F. Caraco, D. L. Correll, R. W. Howarth, A. N. Sharpley, and V. H. Smith (1998), Nonpoint pollution of surface waters with phosphorus and nitrogen, Ecol. Appl., 8(3), 559-568, doi:10.1890/10510761(1998)008[0559:NPOSWW]2.0.CO;2.

Castellano, M. J., J. P. Schmidt, J. P. Kaye, C. Walker, C. B. Graham, H. Lin, and C. J. Dell (2010), Hydrological and biogeochemical controls on the timing and magnitude of nitrous oxide flux across an agricultural landscape, Global Change Biol., 16(10), 2711-2720, doi:10.1111/ j.1365-2486.2009.02116.x.

Chapuis-Lardy, L., N. Wrage, A. Metay, J. L. Chotte, and M. Bernoux (2007), Soils, a sink for N2O? A review, Global Change Biol., 13(1), 1-17, doi:10.1111/j.1365-2486.2006.01280.x.

Davidson, E. A. (1991), Fluxes of nitrous oxide and nitric oxide from terrestrial ecosystems, in Microbial Production and Consumption of Greenhouse Gases: Methane, Nitrogen Oxides, and Halomethanes, edited by J. E. Rogers and W. B. Whitman, pp. 219-235, Am. Soc. for Microbiol., Washington, D. C.

Davidson, E. A., and W. T. Swank (1986), Environmental parameters regulating gaseous nitrogen losses from two forested ecosystems via nitrification and denitrification, Appl. Environ. Microbiol., 52(6), 1287-1292.

Davidson, E. A., M. Keller, H. E. Erickson, L. V. Verchot, and E. Veldkamp (2000), Testing a conceptual model of soil emissions of nitrous and 
nitric oxides, BioScience, 50(8), 667-680, doi:10.1641/0006-3568(2000) 050[0667:TACMOS]2.0.CO;2.

Del Grosso, S. J., W. J. Parton, A. R. Mosier, D. S. Ojima, A. E. Kulmala and S. Phongpan (2000), General model for $\mathrm{N}_{2} \mathrm{O}$ and $\mathrm{N}_{2}$ gas emissions from soils due to dentrification, Global Biogeochem. Cycles, 14(4), 1045-1060, doi:10.1029/1999GB001225

Firestone, M. K., and E. A. Davidson (1989), Microbiological basis of NO and $\mathrm{N}_{2} \mathrm{O}$ production and consumption in soil, in Exchange of Trace Gases between Terrestrial Ecosystems and the Atmosphere, edited by M. O. Andreae and D. Schimel, pp. 7-21, John Wiley and Sons, New York.

Firestone, M. K., M. S. Smith, R. B. Firestone, and J. M. Tiedje (1979), Influence of nitrate, nitrite, and oxygen on the composition of the gaseous products of denitrification in soil, Soil Sci. Soc. Am. J., 43(6), 1140-1144, doi:10.2136/sssaj1979.03615995004300060016x.

Firestone, M. K., R. B. Firestone, and J. M. Tiedje (1980), Nitrous oxide from soil denitrification - factors controlling its biological production, Science, 208(4445), 749-751, doi:10.1126/science.208.4445.749.

Forster, P., et al. (2007), Changes in atmospheric constituents and in radiative forcing, in Climate Change 2007: The Physical Science Basis. Contribution of Working Group I to the Fourth Assessment Report of the Intergovernmental Panel on Climate Change, edited by S. Solomon et al., pp. 129-234, Cambridge Univ. Press, Cambridge, U. K.

Gilmour, J. T. (1984), The effects of soil properties on nitrification and nitrification inhibition, Soil Sci. Soc. Am. J., 48(6), 1262-1266, doi:10.2136/sssaj1984.03615995004800060012x.

Grant, R. F., and E. Pattey (2008), Temperature sensitivity of $\mathrm{N}_{2} \mathrm{O}$ emissions from fertilized agricultural soils: Mathematical modeling in ecosystems, Global Biogeochem. Cycles, 22(4), GB4019, doi:10.1029/ 2008GB003273.

Groffman, P. M. (1991), Ecology of nitrification and denitrification in soil evaluated at scales relevant to atmospheric chemistry, in Microbial Production and Consumption of Greenhouse Gases: Methane, Nitrogen Oxides, and Halomethanes, edited by J. E. Rogers and W. B. Whitman, pp. 201-217, Am. Soc. for Microbiol., Washington, D. C.

Groffman, P. M., J. M. Tiedje, G. P. Robertson, and S. Christensen (1987), Denitrification at different temporal and geographical scales: Proxima and distal controls, in Advances in Nitrogen Cycling in Agricultural Ecosystems, edited by J. R. Wilson, pp. 174-192, CAB International, Oxon, UK.

Groffman, P. M., E. A. Holland, D. D. Myrold, G. P. Robertson, and X. Zou (1999), Denitrification, in Standard Soil Methods for Long-Term Ecological Research, edited by G. P. Robertson et al., pp. 272-288, Oxford Univ. Press, Oxford, U. K.

Groffman, P. M., R. Brumme, K. Butterbach-Bahl, K. E. Dobbie, A. R. Mosier, D. Ojima, H. Papen, W. J. Parton, K. A. Smith, and C. WagnerRiddle (2000), Evaluating annual nitrous oxide fluxes at the ecosystem scale, Global Biogeochem. Cycles, 14(4), 1061-1070, doi:10.1029/ 1999GB001227.

Groffman, P. M., M. A. Altabet, J. K. Bohlke, K. Butterbach-Bahl, M. B. David, M. K. Firestone, A. E. Giblin, T. M. Kana, L. P. Nielsen, and M. A. Voytek (2006), Methods for measuring denitrification: Diverse approaches to a difficult problem, Ecol. Appl., 16(6), 2091-2122, doi:10.1890/1051-0761(2006)016[2091:MFMDDA]2.0.CO;2.

Groffman, P. M., K. Butterbach-Bahl, R. W. Fulweiler, A. J. Gold, J. L. Morse, E. K. Stander, C. Tague, C. Tonitto, and P. Vidon (2009), Challenges to incorporating spatially and temporally explicit phenomena (hotspots and hot moments) in denitrification models, Biogeochemistry, 93(1-2), 49-77, doi:10.1007/s10533-008-9277-5.

Harms, T. K., and N. B. Grimm (2008), Hot spots and hot moments of carbon and nitrogen dynamics in a semiarid riparian zone, J. Geophys. Res., 113, G01020, doi:10.1029/2007JG000588.

Harms, T. K., and N. B. Grimm (2012), Responses of trace gases to hydrologic pulses in desert floodplains, J. Geophys. Res., 117, G01035, doi:10.1029/2011JG001775.

Hernandez, M. E., and W. J. Mitsch (2006), Influence of hydrologic pulses, flooding frequency, and vegetation on nitrous oxide emissions from created riparian marshes, Wetlands, 26(3), 862-877, doi:10.1672/02775212(2006)26[862:IOHPFF]2.0.CO;2.

Hothorn, T., K. Hornik, M. A. van de Wiel, and A. Zeileis (2008), Implementing a class of permutation tests: The coin package, J. Stat. Softw., 28(8), 1-23.

Kemp, M. J., and W. K. Dodds (2002), The influence of ammonium, nitrate, and dissolved oxygen concentrations on uptake, nitrification, and denitrification rates associated with prairie stream substrata, Limnol. Oceanogr., 47(5), 1380-1393, doi:10.4319/1o.2002.47.5.1380.

Klemedtsson, L., K. von Arnold, P. Weslien, and P. Gundersen (2005), Soil $\mathrm{CN}$ ratio as a scalar parameter to predict nitrous oxide emissions, Global Change Biol., 11(7), 1142-1147, doi:10.1111/j.1365-2486.2005.00973.x.
Knowles, R. (1982), Denitrification, Microbiol. Rev., 46(1), 43-70.

Livingston, G. P., and G. L. Hutchinson (1995), Enclosure-based measurement of trace-gas exchange: Applications and sources of error, in Biogenic Trace Gases: Measuring Emissions from Soil and Water, edited by P. A. Matson and R. C. Harriss, pp. 14-51, Blackwell Sci., Cambridge, Mass.

McGill, B. M., A. E. Sutton-Grier, and J. P. Wright (2010), Plant trait diversity buffers variability in denitrification potential over changes in season and soil conditions, PLOS ONE, 5(7), e11618, doi:10.1371/journal. pone. 0011618 .

McQuarrie, A. D. R., and C.-L. Tsai (1998), Regression and Time Series Model Selection, World Sci., London, U. K., doi:10.1142 9789812385451.

Mitsch, W. J., J. W. Day, J. W. Gilliam, P. M. Groffman, D. L. Hey, G. W. Randall, and N. M. Wang (2001), Reducing nitrogen loading to the Gulf of Mexico from the Mississippi River Basin: Strategies to counter a persistent ecological problem, BioScience, 51(5), 373-388, doi:10.1641/0006-3568(2001)051[0373:RNLTTG]2.0.CO;2.

Morse, J. L. (2010), Farm Fields to Wetlands: Biogeochemical Consequences of Re-Flooding in Coastal Plain Agricultural Lands, Duke Univ. Press, Durham, N. C.

Morse, J. L., M. Ardón, and E. S. Bernhardt (2012), Greenhouse gas fluxes in southeastern U.S. coastal plain wetlands under contrasting land uses, Ecol. Appl., 22(1), 264-280, doi:10.1890/11-0527.1.

Natural Resources Conservation Service (NRCS) (2009), Soil Survey Geographic (SSURGO) Database for Tyrrell County, North Carolina, http:// soils.usda.gov/survey/geography/ssurgo/, U.S. Dep. of Agric., Raleigh, N. C.

Needham, R. (2006), Implementation Plan for Agricultural Restoration at Timberlake Farms, Needham Environ. Inc., Wilmington, N. C.

North Carolina Drought Management Advisory Council (2008), Activities report - 2008, 19 pp., Dep. of Environ. and Nat. Resour., Raleigh, N. C. [Available at www.ncdrought.org/documents/2008_annual_report.pdf.]

Olander, L., and K. Haugen-Kozyra (2011), Using biogeochemical process models to quantify greenhouse gas mitigation from agricultural management projects, Rep. NI R 11-03, Nicholas Inst. for Environ. Policy Solutions, Durham, N. C. [Available at http://nicholasinstitute.duke.edu/ ecosystem/t-agg/using-biogeochemical-process.]

Parkin, T. B., A. J. Sexstone, and J. M. Tiedje (1985), Adaptation of denitrifying populations to low soil pH, Appl. Environ. Microbiol., 49(5), 1053-1056.

Philippot, L., J. Andert, C. M. Jones, D. Bru, and S. Hallin (2011), Importance of denitrifiers lacking the genes encoding the nitrous oxide reductase for $\mathrm{N}_{2} \mathrm{O}$ emissions from soil, Global Change Biol., 17(3), 1497-1504, doi:10.1111/j.1365-2486.2010.02334.x.

Poth, M., and D. D. Focht (1985), ${ }^{15} \mathrm{~N}$ kinetic analysis of $\mathrm{N}_{2} \mathrm{O}$ production by Nitrosomonas europaea: An examination of nitrifier denitrification, Appl. Environ. Microbiol., 49(5), 1134-1141.

Reddy, K. R., and W. H. Patrick (1975), Effect of alternate aerobic and anaerobic conditions on redox potential, organic matter decomposition and nitrogen loss in a flooded soil, Soil Biol. Biochem., 7(2), 87-94, doi:10.1016/0038-0717(75)90004-8.

Schindlbacher, A., S. Zechmeister-Boltenstern, and K. Butterbach-Bahl (2004), Effects of soil moisture and temperature on $\mathrm{NO}, \mathrm{NO}_{2}$, and $\mathrm{N}_{2} \mathrm{O}$ emissions from European forest soils, J. Geophys. Res., 109, D17302, doi:10.1029/2004JD004590.

Schlesinger, W. H., and J. A. Andrews (2000), Soil respiration and the global carbon cycle, Biogeochemistry, 48(1), 7-20, doi:10.1023/ A: 1006247623877 .

Schlesinger, W. H., K. H. Reckhow, and E. S. Bernhardt (2006), Global change: The nitrogen cycle and rivers, Water Resour. Res., 42(3), W03S06, doi:10.1029/2005WR004300.

Šimek, M., and J. E. Cooper (2002), The influence of soil pH on denitrification: Progress towards the understanding of this interaction over the last 50 years, Eur. J. Soil Sci., 53(3), 345-354, doi:10.1046/j.1365-2389. 2002.00461.x.

Strauss, E. A., and G. A. Lamberti (2000), Regulation of nitrification in aquatic sediments by organic carbon, Limnol. Oceanogr., 45(8), 1854-1859, doi:10.4319/1o.2000.45.8.1854

Tiedje, J. M., S. Simkins, and P. M. Groffman (1989), Perspectives on measurement of denitrification in the field including recommended protocols for acetylene-based methods, Plant Soil, 115(2), 261-284, doi:10.1007/ BF02202594.

Toma, Y., S. D. Kimura, H. Yamada, Y. Hirose, K. Fujiwara, K. Kusa, and R. Hatano (2010), Effects of environmental factors on temporal variation in annual carbon dioxide and nitrous oxide emissions from an unfertilized bare field on Gray Lowland soil in Mikasa, Hokkaido, Japan, Soil Sci. Plant Nutr., 56(4), 663-675, doi:10.1111/j.1747-0765.2010.00486.x. 
Townsend, A. R., et al. (2003), Human health effects of a changing global nitrogen cycle, Front. Ecol. Environ, 1(5), 240-246, doi:10.1890/15409295(2003)001[0240:HHEOAC]2.0.CO;2.

Ullah, S., and T. R. Moore (2011), Biogeochemical controls on methane, nitrous oxide, and carbon dioxide fluxes from deciduous forest soils in eastern Canada, J. Geophys. Res., 116, G03010, doi:10.1029/ 2010JG001525.

van den Heuvel, R. N., S. E. Bakker, M. S. M. Jetten, and M. M. Hefting (2011), Decreased $\mathrm{N}_{2} \mathrm{O}$ reduction by low soil $\mathrm{pH}$ causes high $\mathrm{N}_{2} \mathrm{O}$ emissions in a riparian ecosystem, Geobiology, 9(3), 294-300, doi:10.1111/ j.1472-4669.2011.00276.x.

Venables, W. N., and B. D. Ripley (2002), Modern Applied Statistics with S, 4th ed., Springer, New York.

Vepraskas, M. J., and S. P. Faulkner (2001), Redox chemistry of hydric soils, in Wetland Soils: Genesis, Hydrology, Landscapes, and Classification, edited by J. L. Richardson and M. J. Vepraskas, pp. 85-105, CRC Press, Boca Raton, Fla

Verhoeven, J. T. A., B. Arheimer, C. Q. Yin, and M. M. Hefting (2006) Regional and global concerns over wetlands and water quality, Trends Ecol. Evol., 21(2), 96-103, doi:10.1016/j.tree.2005.11.015.

Weier, K. L., and J. W. Gilliam (1986), Effect of acidity on denitrifcation and nitrous oxide evolution from Atlantic coastal plain soils, Soil Sci. Soc. Am. J., 50(5), 1202-1205, doi:10.2136/sssaj1986. $03615995005000050022 x$.

Weier, K. L., J. W. Doran, J. F. Power, and D. T. Walters (1993), Denitrification and the dinitrogen/nitrous oxide ratio as affected by soil water, available carbon, and nitrate, Soil Sci. Soc. Am. J., 57, 66-72, doi:10.2136/ sssaj1993.03615995005700010013x.

West, A. W., and G. P. Sparling (1986), Modifications to the substrateinduced respiration method to permit measurement of microbial biomass in soils of differing water contents, J. Microbiol. Methods, 5(3-4), 177-189, doi:10.1016/0167-7012(86)90012-6.
Wixon, D. L., and T. C. Balser (2009), Complexity, climate change and soil carbon: A systems approach to microbial temperature response, Syst. Res. Behav. Sci., 26(5), 601-620, doi:10.1002/sres.995.

Wrage, N., G. L. Velthof, M. L. van Beusichem, and O. Oenema (2001), Role of nitrifier denitrification in the production of nitrous oxide, Soil Biol. Biochem., 33(12-13), 1723-1732, doi:10.1016/S0038-0717(01) 00096-7.

Wu, X., N. Brueggemann, R. Gasche, Z. Shen, B. Wolf, and K. ButterbachBahl (2010), Environmental controls over soil-atmosphere exchange of $\mathrm{N}_{2} \mathrm{O}, \mathrm{NO}$, and $\mathrm{CO}_{2}$ in a temperate Norway spruce forest, Global Biogeochem. Cycles, 24, GB2012, doi:10.1029/2009GB003616.

$\mathrm{Xu}, \mathrm{X}$., H. Tian, and D. Hui (2008), Convergence in the relationship of $\mathrm{CO}_{2}$ and $\mathrm{N}_{2} \mathrm{O}$ exchanges between soil and atmosphere within terrestrial ecosystems, Global Change Biol., 14(7), 1651-1660, doi:10.1111/ j.1365-2486.2008.01595.x.

Yanai, J., T. Sawamoto, T. Oe, K. Kusa, K. Yamakawa, K. Sakamoto, T. Naganawa, K. Inubushi, R. Hatano, and T. Kosaki (2003), Spatial variability of nitrous oxide emissions and their soil-related determining factors in an agricultural field, J. Environ. Qual., 32(6), 1965-1977, doi:10.2134/jeq2003.1965.

Yu, K. W., S. P. Faulkner, and W. H. Patrick (2006), Redox potential characterization and soil greenhouse gas concentration across a hydrological gradient in a Gulf coast forest, Chemosphere, 62(6), 905-914, doi:10.1016/j.chemosphere.2005.05.033.

Yu, K. W., S. P. Faulkner, and M. J. Baldwin (2008), Effect of hydrological conditions on nitrous oxide, methane, and carbon dioxide dynamics in a bottomland hardwood forest and its implication for soil carbon sequestration, Global Change Biol., 14(4), 798-812, doi:10.1111/ j.1365-2486.2008.01545.x.

Zedler, J. B. (2003), Wetlands at your service: Reducing impacts of agriculture at the watershed scale, Front. Ecol. Environ, 1(2), 65-72, doi:10.1890/1540-9295(2003)001[0065:WAYSRI]2.0.CO;2. 